Full Length Article

\title{
Searching for a common methodological ground for the study of politicians' perceived personality traits: A multilevel psycholexical approach
}

\author{
Oleg Gorbaniuk ${ }^{\mathrm{a}, \mathrm{g}, *}$, Wiktor Razmus ${ }^{\mathrm{a}}$, Alona Slobodianyk ${ }^{\mathrm{a}}$, Oleksandr Mykhailych ${ }^{\mathrm{b}}$, \\ Oleksandr Troyanowskyj ${ }^{\mathrm{c}}$, Myroslav Kashchuk ${ }^{\mathrm{d}}$, Maryna Drako ${ }^{\mathrm{a}}$, Albina Dioba ${ }^{\mathrm{e}}$, Larysa Kolisnyk ${ }^{\mathrm{f}}$ \\ ${ }^{\text {a } T h e ~ J o h n ~ P a u l ~ I I ~ C a t h o l i c ~ U n i v e r s i t y ~ o f ~ L u b l i n, ~ L u b l i n, ~ P o l a n d ~}$ \\ ${ }^{\mathrm{b}}$ National Aviation University, Kyiv, Ukraine \\ ${ }^{\mathrm{c}}$ National University Odessa Law Academy, Odessa, Ukraine \\ ${ }^{\mathrm{d}}$ Ukrainian Catholic University, Lviv, Ukraine \\ e O.M. Beketov National University of Urban Economy in Kharkiv, Kharkiv, Ukraine \\ ${ }^{\mathrm{f}}$ National Mining University, Dnipropetrovsk, Ukraine \\ ${ }^{\mathrm{g}}$ University of Zielona Gora, Zielona Gora, Poland
}

\section{A R T I C L E I N F O}

\section{Article history:}

Received 21 November 2016

Accepted 16 May 2017

Available online 20 May 2017

\section{Introduction}

For a fairly long time, research on political behavior have focused on the exploration of factors influencing voter decisions (Blais \& St-Vincent, 2011; Cwalina, Falkowski, Newman, \& Vercic, 2004; O'Cass, 2002; O'Cass \& Pecotich, 2005; Schoen \& Schumann, 2007; Wang, 2016). Out of many factors, the key one is considered to be the image of a politician or of the party that a politician represents (Gorbaniuk, Kusak, Kogut, \& Kustos, 2015; Koppensteiner \& Stephan, 2014). Image is a special kind of idea formed in the voter's mind concerning a politician's characteristics, which, by evoking certain associations, becomes the source of attitudes and influences electoral behavior (Capelos, 2010; Winther Nielsen \& Vinæs Larsen, 2014).

Many scholars believe that the main component of a politician's image is his or her perceived personality traits (Bartels, 2002; Caprara, Schwartz, Vecchione, \& Barbaranelli, 2008; Catellani \& Alberici, 2012; Fridkin \& Kenney, 2011; Miller, Wattenberg, \& Malanchuk, 1986; Peterson, 2005). Most of the studies to date on the structure of personality traits attributed to politicians and on

\footnotetext{
* Corresponding author.

E-mail addresses: oleg.gorbaniuk@gmail.com (O. Gorbaniuk),wrazmus@gmail. com (W. Razmus), olenka.slobodjanyk@gmail.com (A. Slobodianyk), alexandr@ prland.kiev.ua (O. Mykhailych), atroyanovsky@gmail.com (O. Troyanowskyj), miroslav@ucu.edu.ua (M. Kashchuk), marina.drako@gmail.com (M. Drako), dio.albina@gmail.com (A. Dioba),klarisaa@ukr.net (L. Kolisnyk).
}

their significance in determining political preferences (Caprara, Barbaranelli, \& Zimbardo, 1997, 2002; Koppensteiner \& Grammer, 2010; Koppensteiner, Stephan, \& Jäschke, 2015) have been based on the structure of personality traits from the five factor model. The assumption that this model would describe politicians' perceived personality traits accurately was not confirmed by research results (Caprara et al., 1997, 2002). Investigators obtained a smaller number of politicians' perceived personality traits than the five factor model posits. This means that using this model in the study of politicians' perceived personality traits is not a good solution and that further exploratory and systematizing research in this area is needed.

The aim of this article is to propose a uniform procedure of investigating the structure of politicians' perceived personality traits using the methodology borrowed from psycholexical studies (Angleitner, Ostendorf, \& John, 1990; Saucier \& Goldberg, 1996). The lexical approach has enabled the simultaneous application of most of the major criteria for the goodness of a structural model and has created more potential for agreement on a scientific taxonomy (Saucier \& Srivastava, 2015). The procedure, comprising several stages, will be presented as it was applied in a research project conducted in Ukraine in 2011-2014. We believe that similarly to psycholexical research, which concerns particular languages - also research on the structure of politicians' perceived personality traits should be conducted for each country separately. The specificity of a particular country, its culture, and its political scene may play an important role in this respect. 
1.1. The personalization of politics and the significance of politicians' personality traits in determining political preferences

Observations made by researchers studying the political scene indicate that ideological differences between politicians' programs and views are still important to voters but their importance is gradually decreasing (Caprara \& Zimbardo, 2004; Miller et al., 1986). At the same time, the importance of voter-perceived personality traits in politicians' image is observed to be growing to such an extent that some political scientists have proclaimed the onset of a new, candidate-focused era in politics as early as the beginning of the 1990s (Wattenberg, 1991). A content analysis of answers to open-ended questions in pre-election polls in Canada revealed already in the 1970 s and 1980 s that more than $75 \%$ of comments concerned politicians' personality traits (Brown, Lambert, Kay, \& Curtis, 1988).

What is characteristic of the new democracies emerging in Eastern Europe is the tendency for parties to be built around leaders rather than for leaders to emerge from party organizations (Cwalina, Falkowski, \& Kaid, 2000). Frequent changes of party names, prominent politicians moving from one party to another or leaving a party to build their own political group - these are common phenomena in Ukraine as well. With an unstable image of a political party, beliefs concerning the personality traits of politicians may be the anchor around which information about the politician as a person is organized, enabling the prediction of his or her behavior, including the assessment of consistency in fulfilling election promises.

Observations concerning the growing role of politicians' perceived personality traits in determining electoral preferences have been confirmed in numerous studies (Bartels, 2002; Fridkin \& Kenney, 2011; Miller et al., 1986). The personification of politics may be regarded as a manifestation of the individualization of social life, where people want to perceive themselves and others above all as individuals rather than as representatives of a group (Garzia, 2011). This largely results from the increasing role of the media in politics (Caprara \& Zimbardo, 2004; King, 2002). The exploration of differences in the perception of politicians' personality traits is important for several reasons. Firstly, scholars believe that relying on politicians' personality traits enables respondents to organize information about a particular politician in terms of a few basic dimensions. Every day people evaluate other people's personality traits, which means this is a routine operation for them (Fridkin \& Kenney, 2011). As relatively stable human characteristics, traits make it possible for voters to predict politicians' behaviors (Catellani \& Alberici, 2012). Secondly, numerous studies have shown that politicians' perceived personality traits are significant predictors of voter preferences (Bartels, 2002; Fridkin \& Kenney, 2011; Miller et al., 1986). Interestingly, politicians' perceived personality traits explain voter preference to a greater degree than do values attributed to politicians (Caprara et al., 2008). More recent studies also show that a tendency to be guided by politicians' perceived personality traits in developing political preferences is found not only in late deciders but also in early deciders (Catellani \& Alberici, 2012). Investigating politicians' perceived personality traits is important from both the theoretical and the practical points of view.

\subsection{The dimensions of politicians' perceived personality}

Studies on politicians' perceived personality traits have been conducted from the perspective of social perception and concerned attribution processes (e.g. Capelos, 2010; Pancer, Brown, Gregor, \& Claxton-Oldfield, 1992) or from the perspective of personality psychology (e.g. Caprara et al., 1997, 2002; Miller \& Miller, 1976; Pancer et al., 1992). The latter can be divided into two types: exploratory and confirmatory. The aim of exploratory studies was to identify the most important dimensions of politicians' perceived personality by means of an unstructured instrument, without hypothesizing what dimensions these are. Notable examples of the latter include the study by Pancer, Brown, and Barr (1999). Using a list of adjectives constructed on the basis of an earlier analysis of free associations, Pancer et al. (1999) did research among students from the United States, Canada, and the United Kingdom, in which, using factor analysis, they extracted three dimensions of politicians' perceived image: Charisma, Competence, and Integrity. Another example of this kind of approach is analyses performed on the basis of data yielded by open-ended responses on candidate likes and dislikes in the 1972 ANES (American National Election Study) (Miller \& Miller, 1976). The investigators distinguished five dimensions of a politician's image, four of which refer to personality traits: Competence (experience, ability), trust (honesty, integrity), Reliability (responsibility, stability), Leadership Appeal (inspiring, communicative), and Personal Appearance (age, other demographic features).

A different, confirmatory strategy was chosen by Caprara et al. (1997, 2002), who conducted a series of two studies in Italy and in the United States using a structured list of 25 adjectives, compiled earlier for the purpose of measuring the Big Five in ordinary people. It was established in the course of these studies that whereas individuals from outside the realm of politics (a sportsperson and a TV star) were perceived on five classic dimensions typical of the general population, politicians (Berlusconi, Prodi, Clinton, Dole) were perceived on a reduced number of dimensions. In the case of Italian politicians, the factor structure was limited to two dimensions (Energy/Innovation and Honesty/ Trustworthiness), whereas in the case of American politicians it was limited to three dimensions, two of them similar to those in the Italian study (Energy/Innovation, Agreeableness/Conscientious ness) and the third extracted factor not named by the authors (Caprara et al., 1997). The structure of the perception of politicians was identical in various groups of voters and did not depend on the respondents' political preferences. A study conducted five years later based on the same list of adjectives confirmed the twodimensional structure of the perception of the personality of prominent figures in Italian politics.

Analogous research aimed at identifying the key dimensions of politicians' perceived personality has also been done in Poland (Błaszczyk \& Gorbaniuk, 2009; Gorbaniuk, 2009). However, it differed from Caprara's in that it concerned a larger number of politicians (24) and involved a longer list of adjectives (148), which judges selected from a larger list of 410 adjectives as those that differentiated politicians the most. In analyzing data, levels of analysis were distinguished (individual vs. aggregate). Factor analysis at both the individual and aggregate levels revealed the existence of four dimensions: Competence, Impulsivity/Disagreeableness, Extraversion, and Integrity. Moreover, at both levels of analysis, the dimensions extracted were found to be strictly related to preference for and trust in politicians. The number of dimensions obtained in the Polish studies makes it possible to challenge the thesis advanced by Caprara et al. $(1997,2002)$ about the highly simplified structure of politician's perceived personality traits compared to those of ordinary people. This calls for an analysis of possible reasons and makes it necessary to develop guidelines for research taking into account the specificity of the perception of politicians.

A critical analysis of the existing studies on the perception of politicians reveals a number of obstacles that prevent them from answering the question of the universality of politicians' personality traits as perceived in different countries. First of all, they are limited to individual politicians, which, at the very outset, makes it impossible to generalize research findings to other politicians. Secondly, lists of adjectives structured in accordance with the five-factor 
model used for measuring politicians' image frequently fail to take into account the specificity of the object of study; as a result, they may induce dimensions of perception that are absent from the perception of politicians or omit those that are not present in the perception of ordinary people but significant in the perception of politicians. Thirdly, the different number of personality traits obtained in multidimensional analyses often stems from perception being examined on different levels of abstraction vs. detail instead of the structure of traits being considered as a hierarchical system (cf. De Raad et al., 2010). Summing up, it should be stated that the existence of politicians' universal perceived personality traits is an issue whose resolution requires, above all, the unification of methodological standards in order to ensure their compatibility.

\subsection{Identifying the universal dimensions of personality descriptions in psycholexical studies}

When looking for points of reference in establishing the number and content of the dimensions of politicians' perceived personality traits, it is necessary to relate these dimensions to the perceived personality of ordinary people. The lexical approach can not only constitute the appropriate ground for such comparisons but also provide guidelines for a research procedure making it possible to identify politicians' culturally universal perceived personality traits on the basis of a proven methodology of identifying them.

For over half a century, the universal personality traits have been an area of intensive psychological explorations. According to the lexical assumption formulated by Goldberg (1981) the most important traits accounting for individual differences between people are encoded in natural languages. The more important a particular trait is to individuals' social functioning, the more expressions - for example synonyms or antonyms - correspond to it in the lexicon of the language. Analyzing the structure of the lexicon used for describing the personality traits of ordinary people (or, specifically, of politicians) in various countries, it is possible to identify universal and culture-specific dimensions of personality. A typical psycholexical study comprises two main stages: (1) a qualitative study in the form of a lexical taxonomy, whose aim is to select a representative sample of personality descriptors from the lexicon of a given natural language, and (2) a quantitative study, whose aim is to identify the structure of the selected sample of personality-descriptive terms using factor analysis. The results of research carried out independently in seven languages - mainly Western - allowed for distinguishing six personality factors (the Big Six) replicable in each of the cultures considered: Extraversion, Agreeableness, Conscientiousness, Emotionality/Emotional Stability, Intellect, Honesty-Humility (Ashton et al., 2004). Compared to the Big Five (Goldberg, 1990), the Honesty-Humility dimension was a novelty. By contrast, a comparison of 14 trait taxonomies revealed that only three factors of personality description are fully replicable across languages (Extraversion, Agreeableness, and Conscientiousness) (De Raad et al., 2010). Using the unrestricted approach in the selection of personality descriptors produced the Big Seven structure, with two additional factors called Negative and Positive Valence (Almagor, Tellegen, \& Waller, 1995). Because the outcome of the first of the above stages determines the outcome of the second, psycholexical taxonomy is the key to the entire project (Peabody \& Goldberg, 1989; Saucier, 1997). A comparison of the results of Italian, American, and Polish research concerning politicians with results concerning ordinary people shows that politicians are always perceived on a smaller number of dimensions in comparison to the Big Five or Six. A question therefore arises of whether the lists of adjectives used in the existing studies of politicians' personality traits are representative of the lexicon of natural language used for describing the personality of politicians. According to the lexical assumption, getting to know the structure of this lexicon is the key to resolving the issue of universals in the perception of politicians' personality.

The most influential studies that contributed to the development of current psycholexical taxonomy standards include the taxonomies of English (Allport \& Odbert, 1936; Goldberg, 1981), Dutch (de Raad, Hendriks, \& Hofstee, 1992), and German (Angleitner et al., 1990). In the first step, researchers choose the most complete universal dictionary. Next, from that dictionary, terms are selected that are useful in describing individual differences. In the third step, the selected pool of person descriptors is narrowed down to personality descriptors in accordance with the operative definition of personality adopted by the researchers. In the final step, if necessary, the list of personality descriptors is reduced to a size that enables using it in the form of a questionnaire in quantitative research. The frequency of occurrence in the corpus of a given language and familiarity to users is usually adopted as the additional criterion of reduction. The adaptation of the procedure of psycholexical research for the purposes of studies on the perception of politicians as well as the realization of such studies in various countries creates a chance to identify the key traits in politicians' perceived personality, as in Big Personality Factors, with allowances made for their specificity.

\section{Research problems}

In order to use the lexical taxonomy procedure for exploring the perception of politicians, it is necessary in the first place to extract a sample of the lexicon used for describing politicians. This will allow to answer the question concerning the proportion of personality traits in politicians' image:

Q1: What is the structure of person-related associations attributed to politicians by voters from the perspective of lexical taxonomy?

Many researchers measure politicians' perceived personality traits using standard instruments based on the five-factor model of personality, thereby assuming that the dimensions of politicians' perceived personality are the same as the dimensions of ordinary people's personality. In order to check the validity of such an approach, it is necessary to compare voters' spontaneous descriptions of politicians' personality with the markers of the Big Personality Factors.

Q2: Do personality descriptors used by voters in a natural way to describe politicians correspond to the markers of the Big Personality Factors?

Considering the results of the existing studies on the perception of politicians' personality, one should note that two major sources of variance in the perception of politicians must be distinguished: (1) voters differ in their descriptions of the same politicians (within-politician variance); (2) politicians' media images differ from one another, resulting in the same person describing different politicians differently (between-politician variance).

This distinction is not introduced in studies on the structure of perceived personality traits, although the above sources of variance are present in every peer-rating study. The problem of data aggregation is especially evident if results of individual-level data analysis are not congruent with aggregate data analysis (Ostroff, 1993). In the case of a small number of people described, as in the case of politicians, separating these two levels of data analysis becomes justified, technically possible, and methodologically necessary. This gives rise to a series of further questions:

Q3: What are the dimensions of the perception of politicians at the individual and aggregate levels? Is the structure of perception identical in the two cases?

Does knowledge about politicians' perceived personality traits allow to explain voters' preferences? Apart from descriptive and 
systematizing value, knowledge about the dimensions of differentiation of politicians' personality would thus also acquire explanatory and predictive value. Funk's (1999) review of the literature on political marketing shows that evaluations on the dimensions of competence and morality are the most important in predicting voters' preferences. The next research questions can therefore be formulated as follows:

Q4: Is there a connection between politicians' perceived personality traits and the voter preference they enjoy? Which of those traits have the highest explanatory power?

In order to answer the above research questions, we conducted a series of studies on the perception of Ukrainian politicians. To maximize the generalizability of research results, it is necessary to ensure the representativeness of politicians (representative of the political scene) and personality descriptors (representative of the lexicon of politicians' personality traits). This will increase their chance of being replicable in other countries, assuming the standardization of the proposed research procedure in accordance with the lexical approach in personality studies.

\section{Study I: The lexical taxonomy of descriptions of politicians}

The aim of the first stage of the research was to compile a politician personality lexicon and to test the degree to which it represents the Big Six markers, which will enable us to answer the first (Q1) and the second (Q2) research questions. The appropriate research method, enabling the achievement of these goals, is individual interviews and their analysis using the judges technique.

\subsection{Method}

\subsubsection{The selection of politicians}

Based on an analysis of politicians' popularity polls conducted in 2010,31 politicians were selected who were the most commonly recognized by voters in Ukraine. ${ }^{1}$

\subsubsection{Sample}

The participants were $200^{2}$ people ( $53.8 \%$ women) aged 16 to 83 years $(M=34.35, S D=15.45)$. Individuals were recruited according to region, age and sex quota sampling. Participation in the study was voluntary and did not receive any reward.

\subsubsection{Procedure}

The study was carried out using the individual interview method, from September 2010 to December 2011, in seven cities representing Ukraine's different regions (Lviv, Kyiv, Vinnytsia, Dnipropetrovsk, Odessa, Kharkiv, Simferopol/Crimea). Of the 200 interviews, 127 were held in the respondents' places of residence and 73 were conducted via instant messengers.

The respondents' task was to give the personality traits that they associated with each of those among the 31 politicians whom they recognized. In order to facilitate the identification of politi-

\footnotetext{
${ }^{1}$ Rinat Akhmetov, Mykola Azarov, Raisa Bogatyryova, Inna Bohoslovska, Leonid Chernovetskyi, Anna German, Anatoliy Hrytsenko, Valeriy Khoroshkovsky, Andriy Klyuyev, Borys Kolesnikov, Yuriy Kostenko, Leonid Kravchuk, Leonid Kuchma, Yuriy Lutsenko, Sergiy Lyovochkin, Volodymyr Lytvyn, Viktor Medvedchuk, Oleksandr Medvedko, Oleksandr Moroz, Petro Poroshenko, Nestor Shufrych, Petro Symonenko, Dmytro Tabachnyk, Serhiy Tihipko, Oleh Tyahnybok, Yulia Tymoshenko, Nataliya Vitrenko, Viktor Yanukovych, Arseniy Yatsenyuk, Viktor Yushchenko, Roman Zvarych.

2 In lexical studies, a sufficiently extensive basis for an analysis of personality lexicon is considered to be dictionaries with more than 100,000 entries. They contain between 10,000 and 15,000 nouns and adjectives that qualify as personality descriptors. Previous studies (Gorbaniuk, Markiewicz, Bạkowicz, \& Ratajewska, 2010) showed that respondents generate an average of 2.36 personality descriptors per one politician. To obtain a pool of personality descriptors comparable to an average lexical study, it was necessary to test 200 respondents ( 2.36 descriptors per politician $\times 31$ politicians $\times 200$ subjects $=14,632$ descriptors $)$.
}

cians and to prevent mistakes, the respondents were additionally shown a photo of each politician. The order of the politicians was rotated.

\subsection{Results}

\subsubsection{The psycholexical structure of descriptions of politicians}

In total, 18,905 expressions describing politicians were collected. When repeated associations were taken into account, we identified 2038 morphemically unique personal descriptors that had been used by the respondents for describing politicians' characteristics. In the next step, these descriptors were categorized in accordance with the classification system proposed in the German lexical taxonomy (Angleitner et al., 1990).

The classification was performed independently by five judges with psychological education, trained in psycholexical taxonomy. Interjudge agreement was measured using the alpha coefficient, whose values ranged from 0.77 to 0.95 for subcategories and from 0.88 to 0.95 for superordinate categories.

The judges rated each term's desirability from 1 (extremely undesirable) to 3 (neutral, equally desirable/undesirable) to 5 (very desirable) (interjudge agreement $\alpha=0.96$ ). When the mean was between 1 and 2.49 , the term was classified as negative; at 2.50 to 3.50 it was classified as neutral, and at 3.51 to 5.00 - as positive. Generally, voters tended to name negative attributes (56.6\%) more often than positive ones (33.4\%) when describing politicians.

From the point of view of research objectives, the most valuable lexical category is the category of dispositional descriptors, which are equated with personality descriptors in most psycholexical studies. Adjectives and nouns describing politicians' personality traits occurred 14,310 times in the interviews $(75.7 \%$ of all person-related associations), of which 11,287 (60.1\%) were descriptors of temperament and character (e.g., honest, flexible, straightforward) and 2851 (15.6\%) were descriptors of politicians' abilities and talents (e.g., gifted, smart, eloquent). The remaining descriptors did not concern politicians' personality traits: 2953 (15.6\%) were classified into the category of purely social evaluation (e.g., cool, famous, strange), 606 (3.2\%) were recognized as social effects, 1085 (5.7\%) referred to politicians' worldview (e.g., democratic, anti-Ukrainian, pro-Russian), and 530 (2.8\%) described their external appearance (e.g., tall, fat, bald).

\subsubsection{The structure of politician personality descriptors from the perspective of the Big Six markers}

Among the 14,310 dispositional descriptors, 1070 morphemically unique adjectives and nouns were identified. They were classified by two judges, Ph.D. psychologists, into seven categories corresponding to the six dimensions of the Big Six and to category labeled "Other," which comprised descriptors not classified by the judges into any of the dimensions. We used the list of Big Six markers as the basis for defining the dimensions. This list was established through voting by the authors of lexical taxonomies of ten languages (De Raad et al., 2010). The original list comprises 30 adjectives (15 markers per factor pole) for each of the six factors. Interjudge agreement was assessed using the kappa coefficient; its values ranged from 0.84 to 0.95 depending on the category, which should be considered acceptable agreement coefficients (Table 1).

Table 1 presents the frequency in interviews and the relative proportion of personality descriptors classified unanimously by both judges as descriptors of particular traits included in the Big Six. The Other category comprises descriptors classified into it by at least one judge and descriptors whose classification the two judges differed on. The results of the classification show that voters in Ukraine most often describe politicians in terms of HonestyHumility (25.2\%) and Intellect (23.4\%), less often referring to the dimensions of Emotional Stability (15.7\%) and Agreeableness 
Table 1

The classification of politicians' personality descriptors according to the Big Six markers.

\begin{tabular}{|c|c|c|c|}
\hline \multirow[t]{2}{*}{ Category } & \multicolumn{2}{|c|}{ Interjudge-agreement } & \multirow{2}{*}{$\begin{array}{l}\text { Frequency } \\
\%\end{array}$} \\
\hline & $\kappa$ & $f$ & \\
\hline Extraversion & 0.89 & 469 & $3.3 \%$ \\
\hline Agreeableness & 0.87 & 1743 & $12.2 \%$ \\
\hline Conscientiousness & 0.86 & 1135 & $7.9 \%$ \\
\hline Emotional Stability & 0.94 & 2253 & $15.7 \%$ \\
\hline Intellect & 0.95 & 3343 & $23.4 \%$ \\
\hline Honesty-Humility & 0.93 & 3607 & $25.2 \%$ \\
\hline Others & 0.84 & 1760 & $12.3 \%$ \\
\hline
\end{tabular}

Note: The total number of personality descriptors was 14,310 .

(12.2\%); descriptors connected with Conscientiousness appeared rarely $(7.9 \%)$, and the dimension definitely the least frequent in the descriptions of politicians turned out to be Extraversion (3.3\%).

\subsection{Summary}

The analyses of unguided descriptions of politicians revealed a large proportion of personality traits in their image, amounting to nearly three fourths of all associations. Attributes connected with worldview occurred very seldom and constituted less than $6 \%$ of politician descriptions. If we assume that the frequency of occurrence of particular traits in descriptions reflects their importance in the perception of politicians, then Honesty and Intellect are of key importance whereas the role of Extraversion is marginal. There also appears a considerable number of associations that go beyond the markers of the Big Factors, which may result in a factor structure different from those obtained in research on personality lexicon. This can be conclusively resolved only in quantitative research.

\section{Study II: The structure of personality traits attributed to politicians}

The aim of the second stage of research was to identify the structure of personality traits attributed to politicians at the individual and aggregate levels based on the dispositional descriptors emerged in the qualitative study (Q3). The additional aim was to determine the relationship between the extracted dimensions and voter preference for politicians and to develop scales for measuring politicians' perceived personality traits (Q4).

\subsection{Method}

\subsubsection{The questionnaire}

In order to reduce the number of adjectives, we combined the classic lexical approach and the empirical approach, taking into account not only semantic similarity (cf. Goldberg, 1990) but also the usage frequency of each descriptor in the interviews. The set of 1069 morphemically unique personality descriptors was analyzed in terms of content in order to be narrowed down to a list of the most frequently recurring ones. Ninety-two adjectives with a frequency higher than 40 were treated as benchmarks, which the remaining descriptors were grouped round based on semantic similarity. After the categorization of adjectives that differed semantically from the benchmark ones, additional 31 categories of adjectives were distinguished, representing the frequently occurring groups of associations, and adjectives prototypical for each category were identified according to their meaning and usage frequency in the interviews. Thus, we created the final list of 123 personality-descriptive adjectives - content-validity benchmarks for categories with the highest usage frequency. This is in line with the key premise of the lexical approach, linking semantic representation directly with the social importance criterion.
The list included $48 \%$ of negative adjectives, $11 \%$ of neutral ones, and $41 \%$ of positive ones. From the perspective of the Big Six, the representation of traits in the list was as follows: Extraversion $3.3 \%$, Agreeableness - 15.4\%, Conscientiousness - 9.8\%, Emotional Stability - $15.4 \%$, Intellect - $17.1 \%$, Honesty-Humility - $22.0 \%$, Other $-17.1 \%$. Thus prepared, the list of adjectives is an approximately representative sample (in terms of usage frequency, evaluative structure, and semantic structure) of dispositional descriptors that voters used for describing politicians in the interviews (Appendix A).

A respondent's task was to describe a politician using a list of adjectives on a 5-point scale, from 1 - highly inaccurate, to 5 highly accurate. To make it easier to identify each politician, a photo was placed next to his or her name.

In order to measure attitude, a "thermometer of feelings" for a particular politician was placed at the end of the list of adjectives, using a scale from -50 to +50 , where 0 meant an indifferent attitude. Preference for a particular politician was measured using a question about the likelihood of casting a vote for them if they ran in a presidential or parliamentary election. Responses were given on a scale from 1 = definitely no to 7 = definitely yes.

\subsubsection{Politicians}

Based on an analysis of political polls carried out by public opinion research centers in Ukraine, 25 most commonly recognized politicians in Ukraine were selected. ${ }^{3}$ The selected politicians were assigned to eight sets on a stratified random basis. Each respondent described three politicians. Party affiliations were treated as strata, thanks to which politicians in a set represented various political parties. The order of politicians within a set was rotated.

\subsubsection{Sample}

The participants were 583 students (49.2\% women) aged 1831 years $(M=20.1, S D=1.7)$ studying in five cities representing Ukraine's various regions: Kyiv (183 people), Lviv (120), Odessa (120), Kharkiv (40), and Dnipropetrovsk (120). Subjects were selected by accidental sampling method. Because the study was conducted in large academic centers, the respondents represented all the regions of Ukraine. Participation in the study was voluntary and did not receive any reward.

A sample size of 583 meets EFA guidelines for minimum ratios of participants to items $(5: 1)$ and sample size greater than 300 (Gorsuch, 1983). A high ratio of variables to factors, such as that in the present study, actually contributes to the stability of factor loading patterns (Guadagnoli \& Velicer, 1988).

\subsubsection{Procedure}

The study was conducted by means of the household drop-off survey method in March and April 2012. A pollster contacted a respondent living in a dormitory, explained the purpose of the study, and ensured that it was anonymous. The completed questionnaire was collected after about one hour. From the randomly selected set of three politicians, the respondent described only those whom he or she recognized. Out of 625 questionnaires distributed, 583 were returned with at least one politician described wholly by means of the list of adjectives. We thus obtained 1550 descriptions of politicians (which gave an average of 62 descriptions per each of the 25 politicians).

\footnotetext{
${ }^{3}$ Rinat Akhmetov, Mykola Azarov, Viktor Baloha, Leonid Chernovetsky, Anna German, Anatoliy Hrytsenko, Vitaliy Klychko, Borys Kolesnikov, Natalya Korolevska, Leonid Kravchuk, Leonid Kuchma, Yuriy Lutsenko, Volodymyr Lytvyn, Petro Poroshenko, Nestor Shufrych, Petro Symonenko, Dmytro Tabachnyk, Serhiy Tihipko, Oleksandr Turchynov, Oleh Tyahnybok, Yulia Tymoshenko, Nataliya Vitrenko, Viktor Yanukovych, ArseniyYatsenyuk, Viktor Yushchenko.
} 


\subsection{Results}

In order to identify the dimensions of the perception of politicians at the individual level (IL) and the dimensions of differentiation of politicians' personality images at the aggregate level (AL), we performed separate principal component analyses on the data, eliminating, respectively, the variance caused by the specificity of the perceived politician by $M$-data centering (IL) and the differences in the perceptions of the same politician by averaging the respondents' opinions about particular politician (data aggregation, AL).

\subsubsection{The dimensions of politicians' perceived personality at the individual level}

In order to identify the structure of individual differences in the perception of politicians' personality traits, we used $M$-centered data treating each of 1550 evaluations of politicians as a separate case. Centering was done by subtracting the sample mean for a particular politician from all evaluations of that politician within a given variable. In this way, for each variable (personality descriptor), we eliminated the variance stemming from differences between politicians (the mean for each politician is 0 within each variable), thus narrowing the analysis down to the variance stemming from differences in the perception of a given politician (within-politician between-respondent variance, IL). The factors were extracted using the method of principal components based on varimax-rotated solutions. The scree plot shows the last break after the fourth factor, with the eigenvalue for the first factor being especially high $(30.72,7.52,4.59,3.24,2.09,1.79,1.59,1.42,1.37$, 1.27 , etc.). To investigate whether or not the politician personality lexicon would emerge the same factor spaces that had been found in psycholexical studies, we described the one-, two-, three-, four-, and five-factor solutions.

Fig. 1 illustrates the hierarchical emergence of factors from the first unrotated factor through the five-factor varimax-rotated solution, showing the correlations between factors across contiguous solutions. The first unrotated factor was defined by socially desirable versus undesirable terms: the highest loading adjectives included wicked, unwise, corrupt vs. wise, responsible. It comprises adjectives that are extremely charged with emotions, representing several dimensions of the Big Six simultaneously, but it is adjectives describing Honesty that correlate with it most strongly.
In the two-factor solution, the first dimension included attributes associated with asocial and antisocial characteristics, representing the negative extreme of the Morality/Social propriety dimension; it was defined by such adjectives as deceitful, sneaky, corrupt, cheeky. The second dimension included attributes associated with agency, dynamic qualities, and individual ascendancy, as it was most strongly defined by terms such as persistent, professional, strong, or clever.

In the three-factor solution, the earlier dimension describing prosocial versus antisocial characteristics becomes split into two dimensions, of which the first one describes dishonesty (2/1): corrupt, lying, two-faced. Another dimension describes a person's behavior in relations with other people and his or her emotional balance (2/3): aggressive, calm, unrestrained. These dimensions, which can be called, respectively, Dishonesty and Impulsivity, are not subject to any major change, retaining their identity of content up to and including the six-factor solution. The last of the factors extracted in the three-factor solution is a faithful copy of the dimension from the two-factor solution labeled Dynamism.

The optimal solution from the point of view of the scree test is the four-factor solution (individual level; Appendix A). The sums of squared loadings of the four varimax-rotated factors were 18.2, 10.6, 9.9, and 7.3. The total explained variance was $37.4 \%$. For comparison, it is worth noting that in psycholexical studies the explained variance does not usually exceed $30 \%$.

The adjectives that correlate most strongly with the first of the factors extracted in the four-factor solution are those that represent the negative extreme of the Honesty dimension. This factor comprises several facets: (a) telling lies: insincere, dishonest, lying, (b) seeking financial gain at all costs: corrupt, mercenary, greedy, (c) a tendency to take advantage of others in a dishonest way: two-faced, deceitful, sneaky; (d) changing one's views to benefit from it: sycophant, timeserver, traitor, (e) egoism: egoistic, selfish, (f) ruthlessness with people and moral principles: cynical, indifferent, cheeky. The identified clusters of descriptors largely coincide with the symptoms of Machiavellianism in the psychological sense of the term (Jakobwitz \& Egan, 2006).

The second dimension emerged partly through a split of what was the Dynamism dimension in the three-factor solution. It consists of the following six clusters of traits: (a) general intellectual level: clever, stupid, foolish; (b) the ability to make well-thoughtout decisions: wise, reasonable, diplomat; (c) competence: profes-

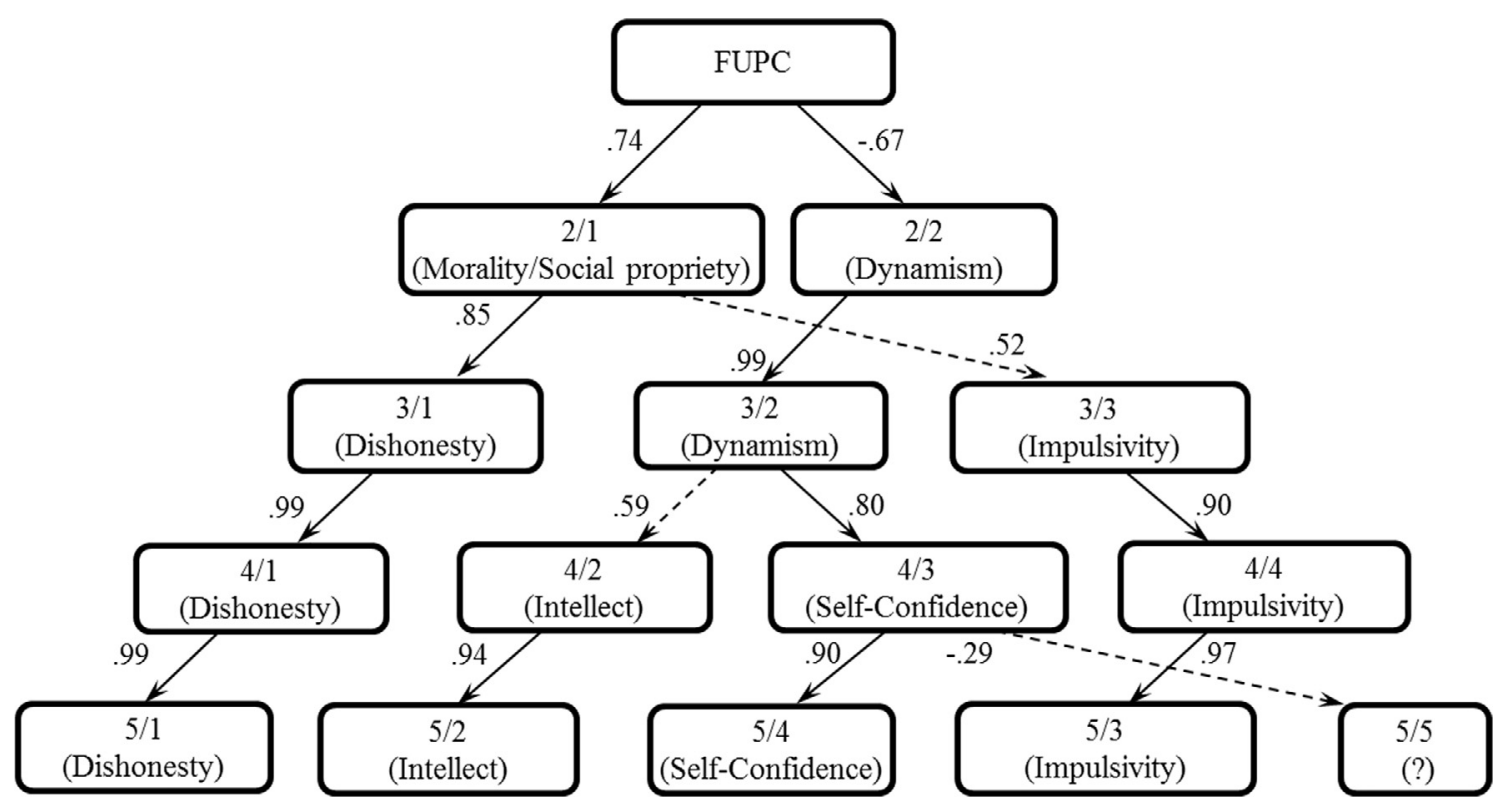

Fig. 1. The five-level hierarchical factor structure based on data from individual level. Note. FUPC - first unrotated principal component. 


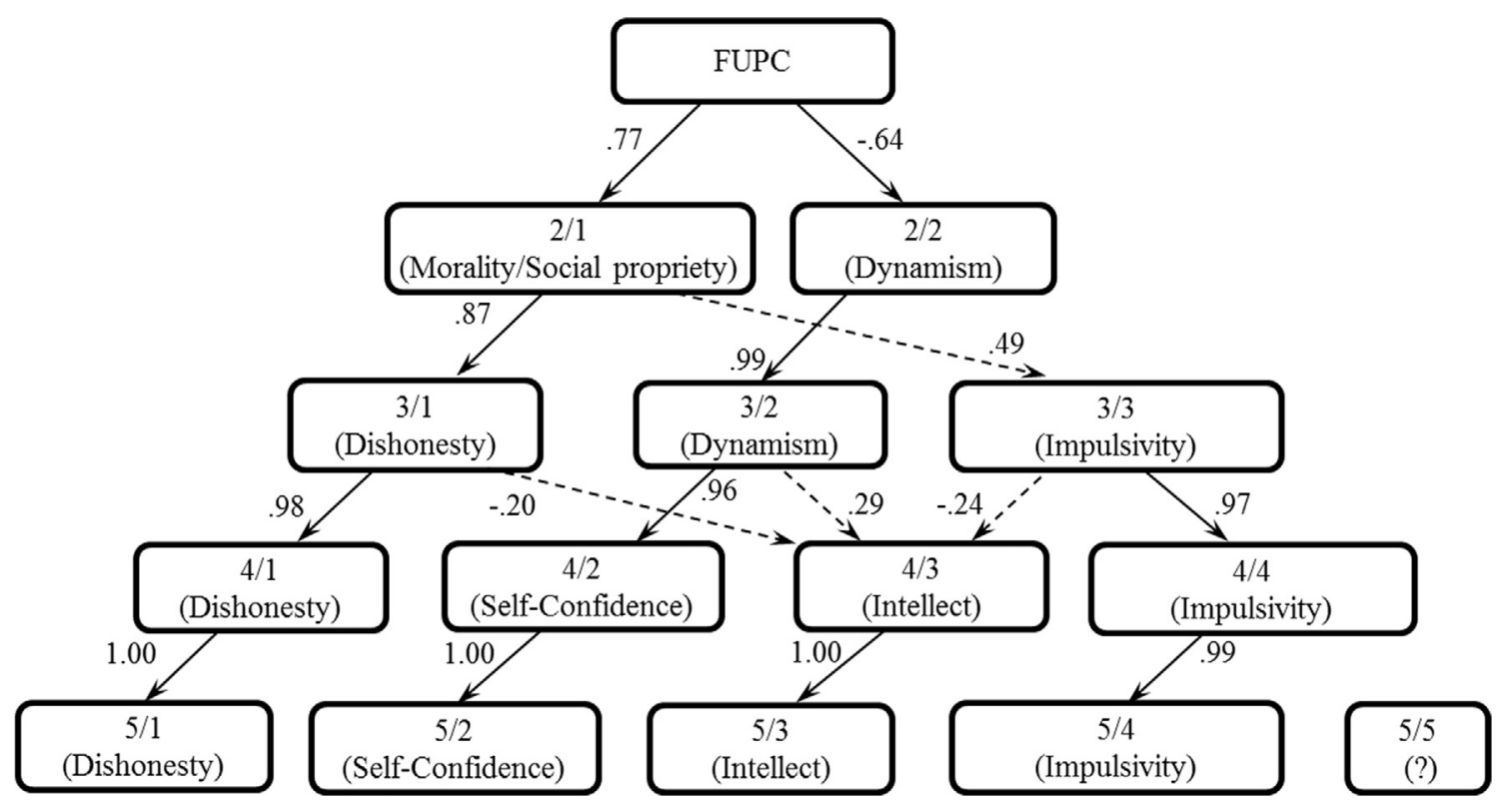

Fig. 2. The five-level hierarchical factor structure based on data from aggregate level.

sional, incompetent; (d) general propriety and intellectual cultivation: educated, well-bred, knowledgeable; (e) giftedness: talented, eloquent, (f) conscientiousness: hardworking, organized, responsible. Except for the weakly correlated adjectives representing conscientiousness, the second dimension coincides with the broadly conceived Intellect dimension from the point of view of personality psychology or with the Competence dimension from the point of view of social psychology.

The third dimension, just like the second, emerged as a result of a split of the Dynamism dimension and comprises the following clusters of traits: (a) purposefulness: persistent, purposeful, ambitious; (b) resoluteness: daring, self-confident, resolute; (c) straightforwardness: straightforward, principled, serious, and (d) initiative: businesslike, enterprising, active. This dimension describes a politician's determination in achieving goals and can be labeled SelfConfidence.

The last, fourth dimension, labeled Impulsivity, consists of two clusters of traits, describing: (a) emotional stability vs. instability: calm, restrained vs. unrestrained, impulsive; (b) confrontationality vs. nonconfrontationality: scandalous, confrontational vs. tolerant, nonconfrontational.

In the five-factor solution, the first four factors are identical in terms of content to those of the previous solution; additionally, the fifth factor is extracted, with a very small number of adjectives loading on it: soft, dreamy, cheerful, weak-charactered. The remaining factor solutions, while retaining the content of the first four factors, lead to the extraction of new factors with single items having the highest correlations. This means that the fourth factor solution should be considered optimal. The use of oblique (oblimin) rotation yields results that are nearly identical in terms of the content of dimensions.

\subsubsection{Differentiation dimensions of politicians' personality at the aggregate level}

The next series of principal component analyses was performed on aggregated data $(A L)$, namely 25 cases of politicians, for each of whom descriptions were averaged in terms of 123 adjectives. By employing this procedure all within-politician variance was removed and the factor analysis was based exclusively on between-politician variance. The purpose of this stage of analyses was to answer the question of what traits politicians differ in from one another, the adopted objectivized measure being the size of difference between the mean profiles of politicians' images. The scree test did not give an unequivocal indication of the number of factors to extract, but the number could be 4 or 5 (69.28, $21.81,8.98,6.40,3.13,1.83,1.54,1.42,1.12,1.00$, etc.).

In the case of one-factor solution, the first factor groups socially undesirable vs. socially desirable descriptors at the extremes of a continuum: maunderer, foolish, irresponsible vs. reasonable, just. In the two-factor solution, this dimension is split (Fig. 2) into (1) Morality/Social propriety: evil, cheeky, deceitful vs. good, tolerant; (2) Dynamism, in which more emphasis is placed on determination in achieving goals: resolute, persistent, purposeful vs. indecisive, weak-charactered. In the three-factor solution, the Dynamism factor does not change, whereas the Morality/Social propriety factor undergoes a split into Dishonesty, with emphasis on Machiavellianism: cynical, deceitful, hypocrite, egoistic vs. good, honest, and Impulsivity, which describes the co-occurrence of confrontationality and emotional instability descriptors: impulsive, scandalous, confrontational vs. calm, restrained.

In the four-factor solution (Appendix B), the Dishonesty and Impulsivity dimensions from the previous solution do not change. As regards Dynamism, it is narrowed down to adjectives describing, strictly, determination in achieving goals; as a result, its content becomes very similar to the dimension from analyses at the individual level, which is why it was labeled likewise: SelfConfidence. The entirely new dimension in the four-factor solution is Intellect, in which, however unlike at the individual level emphasis is placed on oratorical skills, intellectual cultivation, and emotional intelligence: eloquent, educated, and cultured, whereas mental abilities: clever, wise, and logical, were of secondary importance.

In the case of the five-factor solution, the previous factors remain unchanged (correlation from 0.99 to 1.00 ), whereas the fifth factor is loaded by only one adjective: cheerful (0.75). This means that the most cognitively valuable solution, explaining $86.5 \%$ of variance in politicians' image, is the four-factor solution.

\subsubsection{The congruence between politicians' perceived personality dimensions at the individual and aggregate levels}

In order to assess the degree of similarity between the factor structures obtained in data analysis at the individual and aggregate levels, two kinds of coefficients were computed: Tucker's coefficient of congruence, which is a measure of similarity between fac- 
Table 2

Politicians' perceived personality traits and voter preference: multiple regression analysis at the individual and aggregate levels.

\begin{tabular}{|c|c|c|c|c|c|c|}
\hline \multirow[t]{3}{*}{ Explanatory variables } & \multicolumn{6}{|c|}{ Response variables } \\
\hline & \multicolumn{3}{|c|}{ Individual } & \multicolumn{3}{|c|}{ Aggregate level } \\
\hline & Attitude & Parliament & President & Attitude & Parliament & President \\
\hline \multicolumn{7}{|l|}{ Dishonesty } \\
\hline Beta coeff. & $-0.56^{* *}$ & $-0.45^{* *}$ & $-0.41^{* * *}$ & $-0.78^{* *}$ & $-0.68^{* *}$ & $-0.69^{* *}$ \\
\hline Intellect & $0.30^{* *}$ & $0.24^{* *}$ & $0.22^{* *}$ & 0.31 & $0.24^{*}$ & 0.18 \\
\hline Self-Confidence & $0.24^{* *}$ & $0.25^{* *}$ & $0.24^{* *}$ & $0.38^{*}$ & $0.52^{* *}$ & $0.46^{* *}$ \\
\hline Impulsivity & $-0.16^{* *}$ & $-0.10^{* *}$ & $-0.10^{* *}$ & $-0.22^{*}$ & $-0.20^{*}$ & -0.24 \\
\hline$R$ & 0.70 & 0.57 & 0.53 & 0.95 & 0.91 & 0.88 \\
\hline$F$ & $362.49^{* *}$ & $190.13^{* * *}$ & $149.68^{* *}$ & $42.51^{* * *}$ & $25.23^{* *}$ & $16.59^{* *}$ \\
\hline$d f_{1}, d f_{2}$ & 4,1545 & 4,1545 & 4,1545 & 4,20 & 4,20 & 4,20 \\
\hline
\end{tabular}

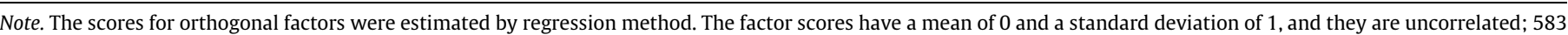
raters and 25 clusters (politicians) produced 1550 observations at the individual level and 25 observations at the aggregate level

${ }^{*} p<0.05$.

$p<0.001$.

tor loadings, and the comparability coefficient, being a measure of similarity between factor scores obtained at the aggregate level and the factor scores that would be obtained in a situation of using factor coefficients computed on the basis of individual data. The congruence coefficients for the pairs of factors were as follows: 0.94 (Dishonesty), 0.95 (Self-Confidence), 0.88 (Intellect), 0.93 (Impulsivity). In the light of the criteria proposed by LorenzoSeva and ten Berge (2006), the obtained Tucker's coefficients attest to the high similarity $(0.85-0.94)$ or identicality $(0.95-1.00)$ of the compared factors. The comparability coefficients were as follows: 0.99 (Dishonesty), 0.98 (Self-Confidence), 0.85 (Intellect), 0.97 (Impulsivity). According to the criterion proposed by Everett (1983), in the case of three dimensions they attest to the equivalence of the factors (0.90-1.00), and in the case of Intellect - to their high comparability. This means that the structure of politicians' perceived personality traits at the individual and group levels is essentially the same and the observed discrepancies are negligible.

\subsubsection{Politicians' perceived personality traits and voter preference}

In order to answer the question of whether or not there is a relationship between personality traits attributed to politicians and the voter preference they enjoy, multiple regression analysis was separately computed for $M$-centered data (IL) and for aggregated data (AL). We used attitude towards and preference for a politician in parliamentary and presidential elections as dependent variables, which were intercorrelated. The correlation between attitude and preference in the parliamentary election was $0.60(p<0.001)$ and the correlation between attitude and preference in the presidential election was $0.55(p<0.001)$. The results of the analyses are presented in Table 2.

They show that personality image explains $87 \%$ of variance in averaged attitude towards a particular politician at the aggregate level $(F(4,20)=42.51, p<0.001 ; R=0.95)$, while the corresponding percentage at the individual level is $48 \%(F(4,1545)=362.49$, $p<0.001, R=0.70$ ). Generally speaking, the structure of the relationship between a politician's image and attitude towards him or her is similar at the aggregate and individual levels. The trait most strongly correlated with attitude towards a politician is Dishonesty ( $\beta=-0.78$ at the AL and $\beta=-0.56$ at the IL). The trait relatively the least correlated with attitude is Impulsivity $(\beta=-0.16$ and $\beta=-0.22$, respectively).

Due to the strong correlation between voter preference for a politician as an MP and as president (0.82), regression equations for the two dependent variables are very similar, and therefore we will only discuss the correlates of the former indicator of voter preference for a politician. Politicians' perceived personality traits explain $80 \%$ of the preference them at the aggregate level, $F$ $(4,20)=25.23, p<0.001$, and $33 \%$ at the individual level, $F$ $(4,1545)=362.49, p<0.001$ (see Table 2). This means that differences between politicians objectivized in the form of mean personality profiles explain $80 \%$ of differences between politicians regarding the mean indices of voter preference they enjoy. Differences between voters in the description of the same politician explain an average of $33 \%$ of differences between voters regarding their preference for that politician.

The relative importance of each perceived trait to the explanation of declared voter preference is similar as in the case of attitude. The main difference is an increase in the importance of politicians' perceived determination in achieving goals (SelfConfidence) and a decrease in the significance of traits associated with broadly understood Intellect at the aggregate level as compared to the individual level.

\subsection{Summary}

The results of the study have shown that the four-factor solution best explains individual differences in the perception of politicians (IL) as well as the differentiation of politician images in terms of personality traits $(A L)$, the structure of perception being nearly identical in the two cases. All of the personality traits distinguished are strictly related to voter preference indicators; the structure of these relations at the individual and aggregate levels is relatively similar.

\section{Study III: Confirmatory multilevel analysis of politicians' perceived personality traits}

The aim of the study was to verify the structure of politicians' perceived personality traits that had been established in the previous stage of research and to verify its relations with preference indicators by examining a sample representing all the regions of Ukraine, where each respondent describes all the politicians in the new political situation in which Ukraine found itself after the events on the Maidan in Kiev at the turn of 2013 and 2014, using multilevel confirmatory analysis (Q3) and multilevel regression analysis (Q5).

\subsection{Method}

\subsubsection{The selection of politicians}

For the purpose of the study, we selected ten politicians running for presidency in 2014 in Ukraine as well as seven most widely recognizable and still active politicians from outside the list of candi- 
dates for the President of Ukraine. ${ }^{4}$ The number of politicians was optimal number to describe by one respondent due to fatigue.

\subsubsection{Sample}

Relative to the number of politician (between level) we evaluated the minimum required sample of 275 (average sample size within a politician), estimated power had to be 0.90 or greater (with $\alpha=0.05$ ), effect size $r=0.20$ and ICC $=0.10$ for repeated measures design. The minimum required sample size for CFA within (a politician) was 316 , taking $\operatorname{RMSEA}(H)=0.070, \operatorname{RMSEA}\left(H_{0}\right)=0.050$, $d f=98$, four factors, four indicators per factor with loadings of 0.65 (estimated values from previous study, see Appendix C).

We studied a larger sample, because some politicians could be unfamiliar to respondents. The participants were 436 students (50.0\% women) aged $17-31$ years $(M=19.7, S D=2.0)$, examined in six Ukrainian cities representing regions that are diverse geographically and historically as well as in terms of political preferences: Lviv (87 people), Uzhorod (83), Odessa (83), Dnipropetrovsk (68), Kharkiv (64), and Kyiv (51). Subjects were selected by accidental sampling method. Participation in the study was voluntary and respondents did not receive any reward.

\subsubsection{Questionnaire and procedure}

Based on the results of the previous stage of research, we selected four adjectives most strongly correlated with each of the four factors at the individual and group levels. As an additional criterion, we considered the frequency of the occurrence of particular adjectives in the descriptions of politicians in interviews and the ICC index for aggregated data. The instrument was tested for internal consistency and test-retest reliability.

Internal consistency was verified on a sample of 210 students from Kyiv, who described 21 politicians a week before the 2012 parliamentary election. Confirmatory factor analysis clearly indicated an acceptable fit of the model to $M$-centered data: $\chi^{2}(96)$ $=242.45, p<0.001 ;$ CFI $=0.961$, RMSEA $=0.050$ (see Appendix C). The following internal consistency coefficients were obtained for particular scales: (1) Self-Confidence ( $\alpha=0.81$ ): persistent, purposeful, resolute, daring, (2) Intellect $(\alpha=0.85)$ : intellectual, educated, cultured, clever; (3) Dishonesty $(\alpha=0.80)$ : crafty, mercenary, lying, two-faced; (4) Impulsivity $(\alpha=0.72)$ : scandalous, confrontational, emotional, calm.

Test-retest reliability of the description of politicians' personality was verified on an independent sample of 52 students from Kyiv, who described three politicians (Arseniy Yatsenyuk, Oleg Lyashko, Petro Poroshenko) twice at a monthly interval. The following test-retest reliability coefficients - computed for each politician, respectively - were obtained for particular scales: $0.86,0.76$, and 0.78 for Dishonesty; 0.64, 0.65, and 0.71 for SelfConfidence; $0.83,0.62$, and 0.86 for Intellect; $0.64,0.60$, and 0.63 for Impulsivity. Considering the changeability of politicians' image, the time interval, and the dynamics of events in Ukraine, the testretest reliability of measurements using the scales developed can be considered acceptable.

The task of each respondent was to describe each of the 17 politicians, whose order in the list was rotated. Preference for a particular politician was measured using a question about the likelihood of casting a vote for them if they ran in a presidential or parliamentary election. Responses were given on a scale from $0 \%$ (definitely no), to $100 \%$ (definitely yes).

The study was conducted a week before the presidential election in Ukraine in May 2014.

\footnotetext{
${ }^{4}$ Arsen Avakov, Mykhaylo Dobkin, Hanna German, Vitaliy Klychko, Oleg Lyashko, Juriy Lutsenko, Andriy Parubiy, Petro Poroshenko, Petro Symonenko, Serhiy Tihipko, Oleksandr Turchynov, Oleg Tyagnybok, Yulia Tymoshenko, Viktor Yanukovych, DmytroYarosh, Arseniy Yatsenyuk, Oleksandr Yefremov.
}

\subsection{Results}

\subsubsection{2-Level confirmatory factor analysis}

In order to answer the question of whether or not and to what extent the assumed structure of traits fits the data at the individual and aggregate levels, two-level confirmatory factor analysis was performed. 2-level CFA decomposes the total sample covariance matrix into pooled within-politician and between-politician covariance matrices and uses these two matrices in the analyses of the factor structure at each level. The total number of observations was 6138 , and the mean number of observations per cluster (i.e., pertaining to the same politician) was 361. Due to worse fit at the individual level, two adjectives were rejected from the last factor that were more weakly correlated with it, namely: emotional and calm. The following indices of fit to input data were obtained for the model presented in Fig. 3: $\chi^{2}(144)=2248.07$, RMSEA $=0.049, C F I=0.939$. The fit index was SRMR(within) $=0.037$ at the individual level and SRMR(between) $=0.068$ at the aggregate level. The obtained fit indices should be regarded as acceptable.

\subsubsection{Internal consistency}

In order to test the internal consistency of items included in the four scales, Cronbach's alpha correlation coefficients and mean correlations between items were computed for each scale for all politicians taken together (centered data) and for each politician separately. The mean values of Cronbach's alpha coefficients ranged between 0.74 and 0.88 , which means the internal consistency of the scales should be considered good or very good.

\subsubsection{2-Level analysis of regression}

Because the distribution of preference for particular politicians was strongly skewed, in order to determine the relationship between a politician's perceived personality traits and voter preference for him or her in presidential elections at the individual level, 2-level logistic regression was performed in which the politician with the highest preference within a respondent received the code of 1 and the others received the code of 0 . The following regression coefficients were obtained for particular traits: Intellect: $b=0.676 \quad(S E=0.074, \quad p<0.001) ; \quad$ Self-Confidence: $\quad b=0.687$ $(S E=0.080, \quad p<0.001) ; \quad$ Dishonesty: $b=-0.448 \quad(S E=0.056$, $p<0.001)$; Impulsivity: $b=-0.146(S E=0.053, p<0.01)^{5}$

\subsection{Summary}

The results of the study have largely confirmed the stability of the factor structure of politicians' perceived personality traits based on adjective markers of particular dimensions (especially at the $\mathrm{AL}$ ), the internal consistency of the scales for measuring perceived personality traits, their test-retest reliability, and the strict relationship of politicians' image with attitude towards and voter preference for them. The only dimension that underwent a split was Impulsivity, which was narrowed down to confrontationality.

It is worth noting that voter preference for a politician in a presidential election is correlated mainly with perceived Self-Confidence and Intellect. Impulsivity is a relatively less significant trait in explaining preference for a politician.

\section{Discussion}

\subsection{Summary of findings}

The use of the procedure adapted from psycholexical studies on the structure of ordinary people's personality traits allowed us to

\footnotetext{
${ }^{5}$ In the case of using a standard 2-level linear regression (in spite of skewness), the regression coefficients were the following: Intellect: $b=4.829(S E=1.191, p<0.001)$; Self-Confidence: $b=6.273$ (SE $=0.847, p<0.001)$; Dishonesty: $b=-7.761(S E=1.031$, $p<0.001)$; Impulsivity: $b=-0.555(S E=1.142, p=0.627)$.
} 


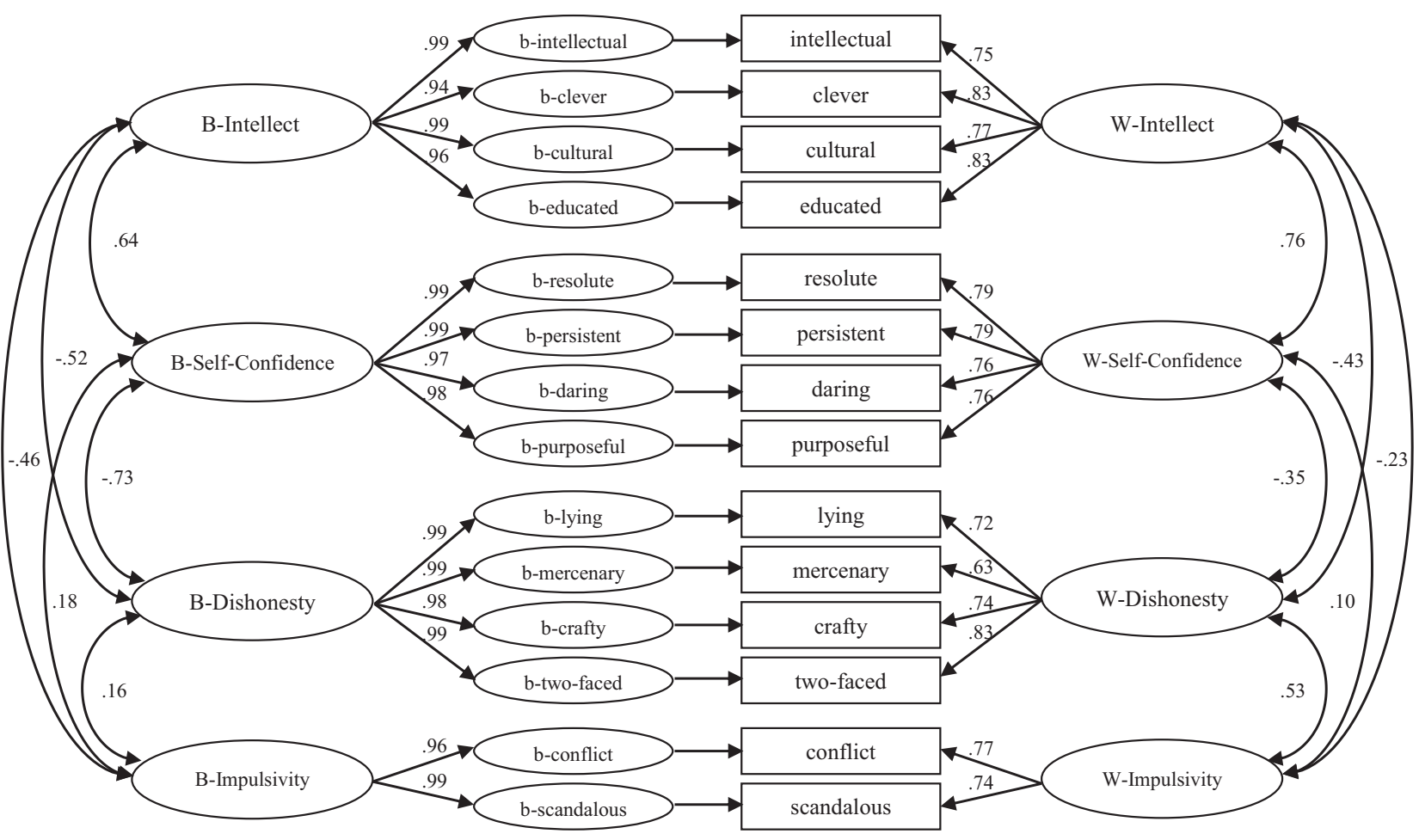

BETWEEN

(between politicians)

WITHIN

(within politician)

Fig. 3. Two-level confirmatory factor analysis.

methodically approach the systematization of the main perceived personality traits of politicians in Ukraine. The identified structure of politicians' perceived personality traits is characterized by comprehensiveness, content validity, social importance and explanatory power, reliability and cross-time stability, as well as generalizability across data levels (individual vs. aggregate), across samples, and across stimuli (different samples of politicians). It meets most of the criteria for a good structural model in psychology (Eysenck, 1991). For the time being, due to the characteristics of our sample of politicians and voters, the scope of generalization of the model is limited to Ukraine.

It was established that natural descriptions of politicians' personality correspond exactly neither to the markers of the Big Six personality factors nor to the markers of the Big Three. This confirms the lack of legitimacy in using standard measures of ordinary people's personality traits for measuring politician's perceived personality. The inference certain traits of politicians may be more difficult due to the impossibility of observing the behaviors relevant to such inference; consequently, associations with some traits may not occur at all in descriptions of politicians. It was established that voters perceive politicians' personality traits on four dimensions: Intellect, Self-Confidence, Dishonesty, and Impulsivity (within-politician level). The same traits differentiate politicians' images from one another (between-politician level). The similarity of the structure of perception and its relation to political preferences at the individual and aggregate levels means that there is no danger of ecological fallacy (Robinson, 1950) and fallacy of composition (Caballero, 1992) in the transfer of a pattern found at one level to the other level. The factors extracted are strictly connected with attitude towards and preference for politicians at both the individual level and the aggregate level. Similarity between the perceived structure of personality traits established in the study of Ukrainian politicians and the results of the few existing studies done in other countries (Caprara et al., 1997, 2002; Gorbaniuk,
2009; Pancer et al., 1999; Wojciszke \& Klusek, 1996) can be found only at the more general level in the case of the two-factor solution (Morality/Social propriety and Dynamism). The results we obtained are comparable to the results of psycholexical studies exploring personality traits attributed to political parties in Poland (Gorbaniuk et al., 2015). Only three factors were extracted there, but all of them appear in a nearly identical form in the perception of Ukrainian politicians: Dishonesty, Disagreeableness, and SelfConfidence. The Intellect dimension is not found in the perception of parties, which can be explained by the specificity of the perceived object. It is also worth noting the similarity of the identified dimensions to the dimensions distinguished based on the analysis of data from the 1972 ANES (Miller \& Miller, 1976). The Intellect dimension is partly identical in terms of content with the Competence dimension, the Self-Confidence dimension corresponds to Reliability, while Dishonesty and Impulsivity are the opposite of the Trust dimension. The fairly high similarity of the structure of personality traits attributed to politicians in American and Ukrainian studies as well as the fact that this structure differs from the five-factor model of personality undermine the legitimacy of using this model for the study of politicians' perceived personality traits.

Our research broadens the existing knowledge in several ways. Firstly, we propose a uniform procedure of investigating politicians' perceived personality traits based on the methodology borrowed from psycholexical studies (Saucier \& Srivastava, 2015). The series of studies we conducted presents the application of this procedure. Previous studies into the structure of politicians' perceived personality traits (Caprara et al., 1997, 2002) had limited possibilities of determining its specificity. We believe that the application of the proposed procedure in other countries will enable researchers to compare results and answer the question of the universality of perceived traits. Studies based on the methodology of psycholexical research will make it possible to 
compile a valid lexicon for describing politicians' perceived personality traits. Secondly, we draw the attention of researchers planning to conduct similar studies to the issue of the level of analysis - that is, to the need to consider both within-and between-politician variances. At least some differences in results regarding the dimensionality of politicians' perceived personality are caused by not taking into account the different levels of data aggregation or by the insufficient number of politicians (i.e., clusters), which can produce a framework of limited generalizability. Thirdly, our research shows the potential significance of perceived personality traits in deciding to vote for a given candidate. Previous studies (Caprara et al., 2008; Catellani \& Alberici, 2012; Costa \& Ferreira da Silva, 2015) already revealed this link, but they focused on a narrow array of politicians' perceived personality traits. Our study, as opposed to previous ones, takes a more complex and multidimensional/multilevel approach to this issue. Fourthly, having higher content validity, the instrument developed on the basis of lexical research can replace the questionnaires currently used for studying politicians' image, intended for self-rating measurement of ordinary people's personality.

\subsection{Limitations and future research}

Although the stage of the research that was crucial for compiling the politician personality lexicon in Ukraine was conducted on a sample with full age range representation, quantitative research was carried out on student samples. In future research it should be tested whether or not the structure of the perception of politicians is identical in a sample representative of the general population. It is worth noting that the measurement of political preferences was based on respondents' declarations, and Study 3 was conducted during a very specific election year; therefore, in the established relationship between perceived personality with preference it is necessary to allow for an overestimate of reality. It is also likely that the variance in preference explained by perceived traits is exaggerated by the lack of consideration of other relevant variables, such as the political orientation of both voters and politicians, which should be taken into account in future studies.

The four-factor solutions were not compared against a clear benchmark provided by the best markers of the Big Six structure because these markers were not included in the study. This increases the likelihood that factor labels could be imprecise especially the dimension called Impulsivity, whose interpretation is closer to Emotional Instability from the perspective of the Big Five/five factor model and closer to Disagreeableness from the perspective of the Big Six/HEXACO. The split of this dimension in Study 3 and the radical decrease in its significance to electoral decisions may be a short-term effect of the new interpretation of
Confrontationality (conflict, scandalous), which had been perceived as destructive (e.g., to the work of the parliament) before the Maidan and may have been interpreted as a more constructive factor after the Maidan - as a factor that led to changes in the country and took on special significance in the face of confrontation with Russia.

The research on politicians' image presented in this article was narrowed down to dispositional traits, which is consistent with the restricted approach, dominant in psycholexical studies. A different direction of exploratory research into the structure of politicians' image is to investigate the full array of associations that politicians bring to mind, in accordance with the unrestricted approach (Almagor et al., 1995; De Raad \& Barelds, 2008), including the descriptors of social effects, pure evaluations, and politicians' worldview; this may result in identifying a greater number of dimensions, going beyond the narrow definition of personality. The results of such studies would make it possible to verify the general statement that politicians' ideology seems less important than their personality - in particular, as the results of the recent U.S. election may indicate, that voters may judge a candidate as having unfavorable traits but still vote for that candidate based on ideology. Although in our research more than $75 \%$ of descriptions of politicians focused on personality traits, the nature of voters' comments may not be a strong indicator of the nature of votes.

Strictly speaking, the presented research allowed us to identify the best emic structure of the perceived personality traits of politicians in Ukraine. The interesting issue of "regional culture" effects is raised by the comparison with results from Poland. In order to answer the question of whether and to what extent it is universal for the perception of personality traits of politicians as such, it is necessary to test the cross-cultural generalizability of this structure by conducting methodologically similar studies the politician personality lexicon in other countries.

The research presented in the paper concerned the perception of politicians' personality traits, but the applied methodology of research and analysis can be successfully extended to personality studies based on peer-rating, since in every study of that kind there are two sources of variance - but two-level analysis, taking the levels of analysis into account and enabling the control of within- and between-ratee variances is possible only where many raters describe the same ratee.

\section{Acknowledgments}

This paper is supported by The John Paul II Catholic University of Lublin grant (Poland) to Oleg Gorbaniuk [agreement number 1/6-1-14-05-01-3512] and Olena Slobodianyk [agreement number 591675/2014].

\section{Appendix A. The factor structure of the perception of politicians at the individual level: the four-factor solution}

\begin{tabular}{|c|c|c|c|c|c|c|c|c|c|c|c|}
\hline \multirow[t]{2}{*}{$\mathrm{Nr}$} & \multicolumn{2}{|c|}{ Frequency $^{*}$} & \multirow[t]{2}{*}{ English } & \multicolumn{4}{|c|}{ Principal components } & \multicolumn{3}{|c|}{ Descriptive stats } & \multirow[t]{2}{*}{ Ukrainian } \\
\hline & Adjective & Category & & 1 & 2 & 3 & 4 & $S D$ & As & K & \\
\hline 71 & 145 & 147 & Corrupt & 0.75 & -0.18 & -0.16 & 0.11 & 1.26 & 0.05 & -0.84 & продажний \\
\hline 108 & 52 & 142 & Two-faced & 0.72 & -0.12 & -0.18 & 0.15 & 1.26 & 0.01 & -0.89 & дволикий \\
\hline 20 & 204 & 209 & Lying & 0.72 & -0.24 & -0.12 & 0.12 & 1.21 & 0.00 & -0.74 & брехливий \\
\hline 31 & 116 & 116 & Deceitful & 0.71 & -0.19 & -0.06 & 0.17 & 1.16 & 0.09 & -0.66 & підступний \\
\hline 84 & 58 & 116 & Sycophant & $\mathbf{0 . 7 0}$ & -0.11 & -0.21 & 0.15 & 1.21 & 0.06 & -0.81 & підлабузник \\
\hline 96 & 72 & 99 & Greedy & 0.70 & -0.11 & -0.11 & 0.15 & 1.15 & -0.05 & -0.69 & жадібний \\
\hline
\end{tabular}


Appendix A (continued)

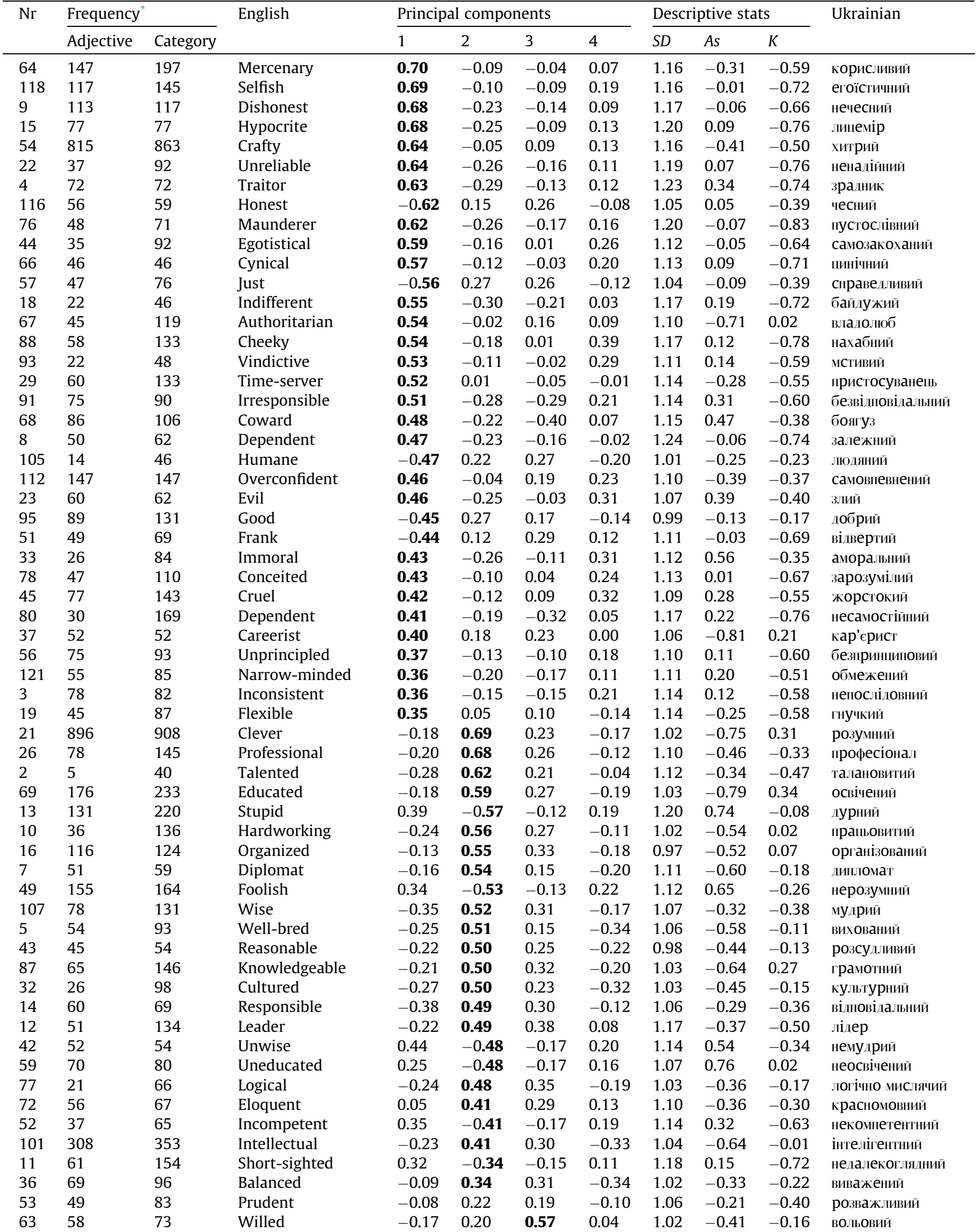


Appendix A (continued)

\begin{tabular}{|c|c|c|c|c|c|c|c|c|c|c|c|}
\hline \multirow[t]{2}{*}{$\mathrm{Nr}$} & \multicolumn{2}{|c|}{ Frequency $^{*}$} & \multirow[t]{2}{*}{ English } & \multicolumn{4}{|c|}{ Principal components } & \multicolumn{3}{|c|}{ Descriptive stats } & \multirow[t]{2}{*}{ Ukrainian } \\
\hline & Adjective & Category & & 1 & 2 & 3 & 4 & $S D$ & As & $K$ & \\
\hline 47 & 96 & 189 & Persistent & -0.12 & 0.34 & 0.56 & 0.02 & 1.00 & -0.68 & 0.24 & наполегливий \\
\hline 109 & 190 & 209 & Purposeful & -0.02 & 0.24 & 0.56 & -0.15 & 0.98 & -0.81 & 0.56 & цілеспрямований \\
\hline 89 & 130 & 154 & Self-confident & 0.03 & 0.12 & 0.54 & 0.04 & 0.94 & -0.81 & 0.57 & впевнений у собі \\
\hline 85 & 28 & 89 & Straightforward & -0.24 & 0.01 & 0.52 & 0.09 & 1.05 & -0.26 & -0.42 & прямолінійний \\
\hline 113 & 47 & 58 & Businesslike & 0.04 & 0.30 & 0.51 & -0.14 & 0.93 & -0.86 & 0.87 & діловий \\
\hline 97 & 52 & 63 & Uncertain & 0.22 & -0.07 & -0.49 & 0.08 & 1.00 & 0.47 & -0.18 & невпевнений \\
\hline 120 & 60 & 60 & Principled & -0.07 & 0.02 & 0.49 & -0.09 & 0.97 & -0.30 & -0.07 & принциповий \\
\hline 38 & 136 & 146 & Strong & -0.21 & 0.40 & 0.47 & 0.03 & 1.01 & -0.51 & 0.11 & сильний \\
\hline 30 & 123 & 135 & Resolute & -0.18 & 0.40 & 0.46 & 0.06 & 1.00 & -0.49 & 0.00 & рішучий \\
\hline 41 & 34 & 44 & Enterprising & -0.20 & 0.35 & 0.44 & 0.06 & 1.01 & -0.38 & -0.22 & ініціативний \\
\hline 34 & 88 & 194 & Active & -0.14 & 0.32 & 0.44 & 0.18 & 1.04 & -0.53 & -0.06 & активний \\
\hline 83 & 20 & 79 & Inventive & -0.09 & 0.36 & 0.42 & 0.06 & 1.08 & -0.23 & -0.42 & винахідливий \\
\hline 86 & 31 & 72 & Pragmatic & 0.08 & 0.03 & 0.41 & -0.12 & 0.97 & -0.23 & 0.11 & прагматичний \\
\hline 92 & 150 & 154 & Ambitious & 0.20 & -0.02 & 0.40 & -0.03 & 1.13 & -0.38 & -0.40 & амбітний \\
\hline 24 & 59 & 183 & Nimble & 0.14 & 0.21 & 0.39 & 0.02 & 1.04 & -0.34 & -0.13 & спритний \\
\hline 103 & 50 & 87 & Consistent & -0.30 & 0.24 & 0.39 & -0.22 & 0.99 & -0.21 & -0.28 & посліддовний \\
\hline 122 & 14 & 38 & Thrifty & -0.19 & 0.16 & 0.38 & -0.25 & 1.01 & -0.36 & 0.00 & хазяйновитий \\
\hline 60 & 53 & 73 & Charismatic & -0.15 & 0.24 & 0.38 & 0.07 & 1.11 & -0.27 & -0.53 & харизматичний \\
\hline 75 & 15 & 58 & Reformer & -0.18 & 0.17 & 0.38 & 0.11 & 1.10 & -0.07 & -0.62 & реформатор \\
\hline 114 & 8 & 60 & Thoughtful & -0.17 & 0.31 & 0.36 & -0.22 & 1.00 & -0.35 & -0.10 & вдумливий \\
\hline 111 & 46 & 82 & Disorganized & 0.28 & -0.23 & -0.36 & 0.31 & 1.02 & 0.46 & -0.26 & неорганізований \\
\hline 28 & 11 & 113 & Strict & 0.09 & 0.21 & 0.36 & 0.05 & 0.99 & -0.11 & -0.23 & строгий \\
\hline 58 & 46 & 46 & Enterprising & 0.10 & 0.20 & 0.35 & -0.09 & 0.98 & -0.54 & 0.22 & підприємливий \\
\hline 82 & 88 & 118 & Aggressive & 0.30 & -0.10 & 0.06 & 0.59 & 1.09 & 0.35 & -0.51 & агресивний \\
\hline 74 & 50 & 69 & Unrestrained & 0.28 & -0.14 & -0.05 & 0.58 & 1.09 & 0.27 & -0.50 & нестриманий \\
\hline 110 & 49 & 61 & Restrained & -0.13 & 0.18 & 0.17 & -0.58 & 1.04 & -0.22 & -0.39 & стриманий \\
\hline 25 & 49 & 51 & Loud & 0.25 & -0.10 & 0.09 & 0.56 & 1.19 & 0.16 & -0.68 & крикливий \\
\hline 115 & 40 & 143 & Scandalous & 0.40 & -0.06 & 0.01 & 0.56 & 1.17 & 0.08 & -0.63 & скандальний \\
\hline 104 & 42 & 46 & Confrontational & 0.38 & -0.06 & 0.03 & 0.55 & 1.10 & 0.07 & -0.63 & конфліктний \\
\hline 119 & 146 & 146 & Balanced & -0.17 & 0.21 & 0.29 & -0.54 & 1.00 & -0.49 & -0.02 & врівноважений \\
\hline 102 & 37 & 67 & Impulsive & 0.16 & -0.01 & 0.24 & 0.51 & 1.09 & -0.06 & -0.47 & імпульсивний \\
\hline 1 & 220 & 252 & Emotional & 0.02 & 0.01 & 0.15 & 0.50 & 1.14 & -0.22 & -0.62 & емоційний \\
\hline 62 & 47 & 96 & Rude & 0.36 & -0.18 & -0.01 & 0.47 & 1.10 & 0.32 & -0.59 & грубий \\
\hline 39 & 84 & 128 & Unstable & 0.35 & -0.28 & -0.15 & 0.46 & 1.12 & 0.41 & -0.42 & неврівноважений \\
\hline 94 & 37 & 138 & Talkative & 0.25 & -0.02 & 0.14 & 0.44 & 1.12 & -0.22 & -0.47 & балакучий \\
\hline 70 & 61 & 73 & Inadequate & 0.37 & -0.29 & -0.17 & 0.42 & 1.15 & 0.55 & -0.32 & неадекватний \\
\hline 40 & 18 & 62 & Tolerant & -0.21 & 0.30 & 0.19 & -0.33 & 1.02 & -0.35 & -0.24 & толерантний \\
\hline 117 & 28 & 54 & Nonconfrontational & -0.13 & 0.27 & 0.15 & -0.33 & 0.95 & -0.19 & -0.13 & компромісний \\
\hline 50 & 23 & 85 & Cautious & 0.09 & 0.15 & 0.16 & -0.27 & 1.01 & -0.50 & -0.06 & обережний \\
\hline \multirow[t]{2}{*}{48} & 17 & 45 & Dreamy & 0.09 & -0.05 & 0.06 & 0.10 & 1.10 & -0.03 & -0.45 & мрійливий \\
\hline & & & Eigenvalue & 18.2 & 10.6 & 9.9 & 7.3 & & & & \\
\hline
\end{tabular}

Numbers in bold indicate strong component loadings.

* Usage frequency in unguided descriptions of politicians during individual interviews; $\mathrm{Nr}$ - the ordinal number of the item in the list of adjectives; $S D$ (standard deviation), As (asymmetry), $K$ (kurtosis) - descriptive statistics of items ( $M$-centered data); 583 raters produced 1550 observations at individual level.

The eigenvalues of the first 10 unrotated factors were $30.72,7.52,4.59,3.24,2.09,1.79,1.59,1.42,1.37$, and 1.27 . 
Appendix B. The factor structure of the perception of politicians at the aggregated levels: the four-factor solution

\begin{tabular}{|c|c|c|c|c|c|c|c|c|c|c|c|}
\hline \multirow[t]{2}{*}{$\mathrm{Nr}$} & \multirow[t]{2}{*}{ English } & \multicolumn{4}{|c|}{ Principal components } & \multicolumn{4}{|c|}{ Descriptive stats } & \multirow[t]{2}{*}{ ICC } & \multirow[t]{2}{*}{ Ukrainian } \\
\hline & & 1 & 2 & 3 & 4 & $M$ & $S D$ & As & $K$ & & \\
\hline 64 & Mercenary & 0.94 & -0.09 & -0.17 & 0.03 & 3.25 & 0.40 & -0.74 & -0.09 & 0.09 & корисливий \\
\hline 54 & Crafty & 0.93 & 0.13 & 0.01 & 0.15 & 3.34 & 0.43 & -1.14 & 0.77 & 0.10 & хитрий \\
\hline 116 & Honest & -0.92 & 0.27 & 0.18 & -0.09 & 2.74 & 0.40 & 0.75 & 1.70 & 0.11 & чесний \\
\hline 66 & Cynical & 0.92 & -0.15 & -0.18 & 0.16 & 2.70 & 0.34 & -0.26 & -0.27 & 0.07 & цинічний \\
\hline 31 & Deceitful & 0.91 & -0.12 & -0.18 & 0.27 & 2.80 & 0.41 & -0.98 & 1.68 & 0.10 & підступний \\
\hline 67 & Authoritarian & 0.90 & 0.02 & -0.02 & 0.25 & 3.77 & 0.34 & -0.70 & 0.20 & 0.07 & владолюб \\
\hline 96 & Greedy & 0.90 & -0.22 & -0.15 & 0.15 & 2.94 & 0.39 & -0.83 & 1.21 & 0.09 & жадібний \\
\hline 118 & Selfish & 0.90 & -0.13 & -0.14 & 0.32 & 2.88 & 0.40 & -0.43 & 0.42 & 0.09 & егоїстичний \\
\hline 15 & Hypocrite & 0.90 & -0.23 & -0.19 & 0.23 & 2.80 & 0.42 & -0.42 & 0.86 & 0.09 & лицемір \\
\hline 108 & Two-faced & 0.89 & -0.37 & -0.10 & 0.13 & 2.96 & 0.40 & -0.81 & 1.42 & 0.09 & дволикий \\
\hline 17 & Wicked & 0.89 & -0.22 & -0.21 & 0.19 & 2.59 & 0.44 & -0.56 & 0.85 & 0.10 & підлий \\
\hline 90 & Insincere & 0.89 & -0.36 & -0.20 & 0.05 & 2.94 & 0.41 & -0.78 & 1.63 & 0.09 & неширий \\
\hline 95 & Good & -0.88 & 0.13 & 0.35 & -0.17 & 3.07 & 0.35 & -0.10 & 0.34 & 0.10 & добрий \\
\hline 20 & Lying & 0.88 & -0.35 & -0.13 & 0.20 & 2.96 & 0.45 & -0.92 & 1.59 & 0.11 & брехливий \\
\hline 71 & Corrupt & 0.87 & -0.41 & -0.17 & 0.06 & 2.88 & 0.44 & -0.53 & 1.34 & 0.09 & продажний \\
\hline 9 & Dishonest & 0.85 & -0.39 & -0.23 & 0.06 & 3.09 & 0.46 & -0.55 & 1.13 & 0.12 & нечесний \\
\hline 27 & False & 0.85 & -0.34 & -0.25 & 0.15 & 2.96 & 0.42 & -0.67 & 1.63 & 0.10 & неправдивий \\
\hline 4 & Traitor & 0.84 & -0.38 & -0.01 & 0.12 & 2.51 & 0.40 & -0.61 & 0.99 & 0.08 & зрадник \\
\hline 23 & Evil & 0.84 & 0.00 & -0.28 & 0.40 & 2.32 & 0.34 & -0.22 & -0.42 & 0.08 & злий \\
\hline 56 & Unprincipled & 0.83 & -0.18 & -0.24 & 0.28 & 2.66 & 0.25 & -0.91 & 1.18 & 0.03 & безпринциповий \\
\hline 18 & Indifferent & 0.83 & -0.37 & -0.29 & 0.06 & 2.67 & 0.38 & -0.27 & 0.03 & 0.08 & байлужий \\
\hline 105 & Humane & -0.83 & 0.19 & 0.38 & -0.14 & 3.25 & 0.40 & 0.26 & 0.24 & 0.12 & людяний \\
\hline 78 & Conceited & 0.82 & 0.07 & -0.33 & 0.21 & 2.92 & 0.28 & -0.34 & 0.11 & 0.04 & зарозумілий \\
\hline 57 & Just & -0.81 & 0.37 & 0.31 & -0.17 & 2.93 & 0.39 & 0.19 & 0.24 & 0.11 & справедливий \\
\hline 93 & Vindictive & 0.80 & 0.07 & -0.26 & 0.32 & 2.63 & 0.38 & 0.03 & -0.83 & 0.08 & мстивий \\
\hline 84 & Sycophant & 0.80 & -0.47 & -0.06 & 0.19 & 2.84 & 0.41 & -0.65 & 1.68 & 0.09 & підлабузник \\
\hline 44 & Egotistical & 0.79 & -0.04 & -0.16 & 0.38 & 2.91 & 0.36 & -0.19 & -0.16 & 0.08 & самозакоханий \\
\hline 51 & Frank & -0.79 & 0.25 & 0.16 & 0.14 & 2.85 & 0.29 & 0.65 & 0.79 & 0.05 & відвертий \\
\hline 88 & Cheeky & 0.78 & -0.07 & -0.36 & 0.44 & 2.74 & 0.46 & -0.52 & -0.39 & 0.11 & нахаб̆ний \\
\hline 45 & Cruel & 0.78 & 0.24 & -0.40 & 0.23 & 2.45 & 0.34 & -0.13 & -0.22 & 0.07 & жорстокий \\
\hline 29 & Timeserver & 0.77 & -0.35 & 0.18 & 0.10 & 3.23 & 0.30 & -1.12 & 1.71 & 0.05 & пристосуванець \\
\hline 33 & Immoral & 0.76 & -0.16 & -0.42 & 0.38 & 2.24 & 0.35 & 0.16 & -0.62 & 0.07 & аморальний \\
\hline 112 & Overconfident & 0.74 & 0.28 & -0.10 & 0.35 & 3.33 & 0.31 & 0.12 & -1.23 & 0.06 & самовпевнений \\
\hline 22 & Unreliable & 0.72 & -0.55 & -0.21 & 0.18 & 2.92 & 0.42 & 0.00 & 1.13 & 0.09 & ненадійний \\
\hline 40 & Tolerant & -0.70 & 0.21 & 0.47 & -0.40 & 3.27 & 0.36 & -0.15 & -0.58 & 0.09 & толерантний \\
\hline 76 & Maunderer & 0.69 & -0.54 & -0.24 & 0.34 & 3.01 & 0.43 & -0.48 & 0.51 & 0.10 & пустосліівний \\
\hline 62 & Rude & 0.67 & 0.00 & -0.59 & 0.30 & 2.40 & 0.42 & 0.46 & -0.31 & 0.11 & грубий \\
\hline 117 & Nonconfrontational & -0.65 & -0.15 & 0.30 & -0.48 & 2.96 & 0.27 & 0.53 & -0.42 & 0.06 & компромісний \\
\hline 121 & Narrow-minded & 0.64 & -0.55 & -0.21 & 0.32 & 2.64 & 0.27 & -0.58 & 1.13 & 0.04 & обмежений \\
\hline 37 & Careerist & 0.63 & 0.53 & 0.12 & 0.04 & 3.84 & 0.27 & 0.20 & 0.51 & 0.04 & кар’єрист \\
\hline 5 & Well-bred & -0.63 & 0.30 & 0.54 & -0.44 & 3.67 & 0.50 & -0.32 & -0.65 & 0.16 & вихований \\
\hline 70 & Inadequate & 0.59 & -0.37 & -0.43 & 0.48 & 2.23 & 0.49 & 0.70 & 0.39 & 0.13 & неадекватний \\
\hline 114 & Thoughtful & -0.57 & 0.41 & 0.50 & -0.39 & 3.35 & 0.28 & -0.36 & -0.69 & 0.06 & вдумливий \\
\hline 49 & Foolish & 0.56 & -0.50 & -0.49 & 0.34 & 2.14 & 0.45 & 0.59 & -0.45 & 0.12 & нерозумний \\
\hline 122 & Thrifty & -0.54 & 0.46 & 0.26 & -0.35 & 3.22 & 0.26 & 0.29 & -0.63 & 0.05 & хазяйновитий \\
\hline 43 & Reasonable & -0.53 & 0.51 & 0.47 & -0.37 & 3.41 & 0.36 & -0.40 & -1.00 & 0.10 & розсудливий \\
\hline 53 & Prudent & -0.53 & 0.44 & 0.14 & -0.45 & 3.09 & 0.18 & 0.24 & 0.19 & 0.02 & розважливий \\
\hline 73 & Cheerful & -0.49 & 0.15 & -0.03 & 0.18 & 3.04 & 0.38 & 0.13 & -0.31 & 0.10 & веселий \\
\hline 35 & Weak-charactered & 0.08 & -0.96 & -0.03 & 0.06 & 2.32 & 0.45 & -0.11 & 0.85 & 0.13 & слабохарактерний \\
\hline 38 & Strong & -0.13 & 0.96 & 0.07 & -0.04 & 3.61 & 0.49 & 0.40 & 0.53 & 0.17 & сильний \\
\hline 30 & Resolute & -0.15 & 0.96 & 0.15 & 0.09 & 3.58 & 0.38 & 0.24 & 0.19 & 0.11 & рішучий \\
\hline 61 & Indecisive & 0.05 & -0.93 & -0.20 & 0.04 & 2.31 & 0.36 & -0.39 & -0.11 & 0.08 & нерішучий \\
\hline 47 & Persistent & -0.24 & 0.92 & 0.18 & -0.03 & 3.64 & 0.35 & 0.39 & -0.09 & 0.10 & наполегливий \\
\hline 97 & Uncertain & 0.17 & -0.92 & -0.01 & 0.00 & 2.30 & 0.35 & -0.36 & 0.13 & 0.09 & невпевнений \\
\hline 6 & Weak & 0.14 & -0.91 & -0.02 & 0.04 & 2.36 & 0.48 & -0.48 & 0.54 & 0.14 & слабкий \\
\hline 89 & Self-confident & 0.10 & 0.91 & 0.04 & 0.15 & 3.91 & 0.35 & 0.51 & -0.07 & 0.10 & впевнений у собі \\
\hline 109 & Purposeful & -0.14 & 0.90 & 0.27 & -0.06 & 3.77 & 0.34 & 0.61 & -0.05 & 0.09 & цілеспрямований \\
\hline 46 & Daring & -0.35 & 0.88 & 0.07 & 0.12 & 3.34 & 0.43 & 0.75 & 0.65 & 0.13 & сміливий \\
\hline 63 & Willed & -0.29 & 0.88 & 0.15 & 0.20 & 3.34 & 0.39 & 0.61 & 0.44 & 0.11 & вольовий \\
\hline
\end{tabular}


Appendix B (continued)

\begin{tabular}{|c|c|c|c|c|c|c|c|c|c|c|c|}
\hline \multirow[t]{2}{*}{$\mathrm{Nr}$} & \multirow[t]{2}{*}{ English } & \multicolumn{4}{|c|}{ Principal components } & \multicolumn{4}{|c|}{ Descriptive stats } & \multirow[t]{2}{*}{ ICC } & \multirow[t]{2}{*}{ Ukrainian } \\
\hline & & 1 & 2 & 3 & 4 & $M$ & $S D$ & As & K & & \\
\hline 24 & Nimble & -0.03 & 0.84 & 0.28 & 0.15 & 3.32 & 0.42 & -0.07 & -0.77 & 0.12 & спритний \\
\hline 68 & Coward & 0.45 & -0.84 & -0.15 & 0.10 & 2.38 & 0.38 & -0.51 & 0.37 & 0.08 & боягуз \\
\hline 123 & Corporate & -0.15 & 0.84 & 0.12 & -0.07 & 3.44 & 0.28 & -0.80 & 1.66 & 0.05 & командний \\
\hline 85 & Straightforward & -0.41 & 0.81 & -0.18 & 0.23 & 3.15 & 0.27 & 0.60 & 0.43 & 0.05 & прямолінійний \\
\hline 8 & Dependent & 0.35 & -0.80 & -0.14 & 0.15 & 3.03 & 0.50 & -0.98 & 1.15 & 0.12 & залежний \\
\hline 28 & Strict & 0.24 & 0.80 & -0.06 & 0.23 & 3.10 & 0.32 & -0.91 & 1.86 & 0.08 & строгий \\
\hline 34 & Active & -0.35 & 0.79 & 0.30 & 0.31 & 3.65 & 0.41 & 0.31 & -0.61 & 0.12 & активний \\
\hline 12 & Leader & -0.34 & 0.79 & 0.22 & -0.12 & 3.38 & 0.49 & 0.46 & -0.52 & 0.13 & лідер \\
\hline 86 & Pragmatic & 0.08 & 0.79 & 0.29 & -0.16 & 3.12 & 0.15 & 0.63 & 0.02 & 0.01 & прагматичний \\
\hline 80 & Dependent & 0.37 & -0.78 & -0.14 & 0.18 & 2.62 & 0.37 & -0.60 & 0.80 & 0.07 & несамостійний \\
\hline 41 & Enterprising & -0.33 & 0.78 & 0.46 & 0.03 & 3.44 & 0.35 & 0.22 & -0.34 & 0.09 & ініціативний \\
\hline 16 & Organized & -0.35 & 0.74 & 0.44 & -0.31 & 3.61 & 0.39 & -0.50 & 0.55 & 0.12 & організований \\
\hline 113 & Businesslike & 0.06 & 0.73 & 0.61 & -0.24 & 3.89 & 0.31 & -0.24 & 1.09 & 0.08 & діловий \\
\hline 11 & Short-sighted & 0.28 & -0.72 & -0.33 & 0.32 & 2.78 & 0.36 & -0.31 & -0.75 & 0.07 & недалекоглядний \\
\hline 3 & Inconsistent & 0.41 & -0.71 & -0.30 & 0.32 & 2.77 & 0.38 & 0.56 & 0.33 & 0.08 & непосліідовний \\
\hline 65 & Soft & -0.36 & -0.71 & 0.42 & -0.18 & 2.51 & 0.29 & 1.20 & 2.49 & 0.05 & м'який \\
\hline 120 & Principled & -0.30 & 0.71 & 0.23 & 0.02 & 3.28 & 0.20 & -0.48 & 0.17 & 0.03 & принциповий \\
\hline 10 & Hardworking & -0.54 & 0.70 & 0.34 & -0.13 & 3.56 & 0.45 & 0.10 & 0.27 & 0.14 & працьовитий \\
\hline 103 & Consistent & -0.46 & 0.70 & 0.33 & -0.28 & 3.12 & 0.31 & -0.43 & -0.08 & 0.07 & послідовний \\
\hline 111 & Disorganized & 0.47 & -0.69 & -0.39 & 0.21 & 2.29 & 0.32 & 0.40 & 0.93 & 0.07 & неорганізований \\
\hline 26 & Professional & -0.31 & 0.69 & 0.52 & -0.31 & 3.56 & 0.40 & -0.10 & -0.20 & 0.10 & професіонал \\
\hline 92 & Ambitious & 0.10 & 0.68 & 0.19 & 0.26 & 3.37 & 0.24 & -0.16 & -1.07 & 0.03 & амбітний \\
\hline 14 & Responsible & -0.53 & 0.68 & 0.34 & -0.28 & 3.29 & 0.39 & -0.51 & 0.94 & 0.10 & відповідальний \\
\hline 83 & Inventive & -0.12 & 0.67 & 0.57 & 0.02 & 3.09 & 0.36 & 0.33 & -0.04 & 0.08 & винахідливий \\
\hline 2 & Talented & -0.56 & 0.65 & 0.36 & -0.10 & 3.31 & 0.50 & 0.16 & 0.27 & 0.15 & талановитий \\
\hline 60 & Charismatic & -0.50 & 0.63 & 0.41 & 0.17 & 3.18 & 0.43 & 0.19 & -0.11 & 0.11 & харизматичний \\
\hline 91 & Irresponsible & 0.55 & -0.63 & -0.32 & 0.34 & 2.53 & 0.40 & 0.15 & 1.26 & 0.09 & безвідповідальний \\
\hline 79 & Serious & -0.30 & 0.59 & 0.31 & -0.39 & 3.63 & 0.34 & -2.10 & 7.27 & 0.09 & серйозний \\
\hline 98 & Stable & -0.44 & 0.59 & 0.10 & -0.51 & 3.13 & 0.28 & 0.24 & 1.44 & 0.05 & стабільний \\
\hline 100 & Stubborn & 0.40 & 0.59 & -0.14 & 0.56 & 3.24 & 0.31 & 0.07 & -0.75 & 0.06 & впертий \\
\hline 58 & Enterprising & 0.35 & 0.59 & 0.38 & -0.34 & 3.58 & 0.31 & 1.04 & 2.07 & 0.07 & підприємливий \\
\hline 48 & Dreamy & -0.45 & -0.58 & -0.04 & 0.32 & 2.89 & 0.30 & 1.94 & 3.99 & 0.05 & мрійливий \\
\hline 13 & Stupid & 0.51 & -0.52 & -0.52 & 0.34 & 2.14 & 0.51 & 0.87 & -0.01 & 0.13 & дурний \\
\hline 75 & Reformer & -0.11 & 0.48 & 0.42 & 0.26 & 2.86 & 0.29 & 0.78 & 1.25 & 0.05 & реформатор \\
\hline 72 & Eloquent & -0.36 & 0.34 & 0.81 & 0.22 & 3.45 & 0.46 & -0.19 & 0.92 & 0.13 & красномовний \\
\hline 55 & Orator & -0.29 & 0.32 & 0.81 & 0.25 & 3.56 & 0.52 & -0.37 & 1.87 & 0.16 & оратор \\
\hline 69 & Educated & -0.46 & 0.33 & 0.78 & -0.07 & 3.90 & 0.45 & -1.39 & 2.05 & 0.14 & освічений \\
\hline 7 & Diplomat & -0.24 & 0.38 & 0.77 & -0.36 & 3.58 & 0.38 & -0.51 & -0.59 & 0.08 & дипломат \\
\hline 19 & Flexible & 0.18 & -0.08 & 0.73 & 0.01 & 3.19 & 0.25 & 0.47 & -0.23 & 0.03 & гнучкий \\
\hline 99 & Communicative & -0.46 & 0.44 & 0.72 & 0.06 & 3.53 & 0.33 & -0.54 & 0.32 & 0.08 & комунікабельний \\
\hline 59 & Uneducated & 0.50 & -0.32 & -0.71 & 0.22 & 2.03 & 0.43 & 1.20 & 1.27 & 0.12 & неосвічений \\
\hline 87 & Knowledgeable & -0.47 & 0.40 & 0.71 & -0.07 & 3.73 & 0.52 & -1.63 & 2.83 & 0.18 & грамотний \\
\hline 21 & Clever & -0.45 & 0.46 & 0.67 & -0.26 & 3.83 & 0.41 & -1.03 & 0.03 & 0.12 & розумний \\
\hline 32 & Cultured & -0.60 & 0.26 & 0.66 & -0.28 & 3.68 & 0.48 & -0.43 & -0.63 & 0.16 & культурний \\
\hline 101 & Intellectual & -0.58 & 0.34 & 0.65 & -0.29 & 3.66 & 0.43 & -0.74 & -0.04 & 0.12 & інтелігентний \\
\hline 52 & Incompetent & 0.53 & -0.39 & -0.63 & 0.29 & 2.51 & 0.40 & 0.71 & -0.53 & 0.09 & некомпетентний \\
\hline 107 & Wise & -0.54 & 0.45 & 0.62 & -0.21 & 3.42 & 0.41 & -0.89 & 0.08 & 0.11 & мудрий \\
\hline 77 & Logical & -0.42 & 0.51 & 0.61 & -0.35 & 3.38 & 0.40 & -0.93 & -0.06 & 0.11 & логічно мислячий \\
\hline 106 & Tidy & -0.25 & 0.53 & 0.58 & -0.17 & 3.97 & 0.29 & -0.11 & 0.65 & 0.07 & охайний \\
\hline 42 & Unwise & 0.54 & -0.43 & -0.58 & 0.37 & 2.28 & 0.45 & 0.76 & -0.45 & 0.12 & немудрий \\
\hline 102 & Impulsive & 0.04 & 0.21 & 0.02 & 0.92 & 2.98 & 0.38 & 0.67 & -0.47 & 0.09 & імпульсивний \\
\hline 1 & Emotional & -0.04 & 0.07 & 0.15 & 0.92 & 3.21 & 0.52 & 0.50 & -0.76 & 0.15 & емоційний \\
\hline 81 & Calm & -0.38 & -0.18 & 0.13 & -0.86 & 3.24 & 0.39 & -0.08 & -0.19 & 0.09 & спокійний \\
\hline 25 & Loud & 0.36 & 0.17 & 0.07 & 0.84 & 2.64 & 0.49 & 0.45 & 0.19 & 0.13 & крикливий \\
\hline 110 & Restrained & -0.36 & 0.16 & 0.21 & -0.83 & 3.21 & 0.37 & -0.16 & -0.72 & 0.10 & стриманий \\
\hline 94 & Talkative & 0.10 & -0.02 & 0.41 & 0.82 & 3.17 & 0.45 & 0.37 & -0.30 & 0.12 & балакучий \\
\hline 115 & Scandalous & 0.50 & 0.04 & -0.11 & 0.82 & 2.75 & 0.49 & 0.15 & -0.85 & 0.13 & скандальний \\
\hline 74 & Unrestrained & 0.41 & -0.07 & -0.34 & 0.80 & 2.55 & 0.38 & 0.18 & -0.42 & 0.09 & нестриманий \\
\hline 104 & Confrontational & 0.49 & 0.06 & -0.16 & 0.78 & 2.76 & 0.45 & 0.20 & -0.65 & 0.13 & конфліктний \\
\hline
\end{tabular}


Appendix B (continued)

\begin{tabular}{|c|c|c|c|c|c|c|c|c|c|c|c|}
\hline \multirow[t]{2}{*}{$\mathrm{Nr}$} & \multirow[t]{2}{*}{ English } & \multicolumn{4}{|c|}{ Principal components } & \multicolumn{4}{|c|}{ Descriptive stats } & \multirow[t]{2}{*}{ ICC } & \multirow[t]{2}{*}{ Ukrainian } \\
\hline & & 1 & 2 & 3 & 4 & $M$ & $S D$ & As & $K$ & & \\
\hline 50 & Cautious & 0.05 & 0.39 & 0.14 & -0.74 & 3.40 & 0.20 & 0.21 & -0.09 & 0.02 & обережний \\
\hline 82 & Aggressive & 0.50 & 0.20 & -0.34 & 0.74 & 2.36 & 0.39 & 0.21 & -0.23 & 0.10 & агресивний \\
\hline 39 & Unstable & 0.46 & -0.25 & -0.32 & 0.73 & 2.37 & 0.43 & 0.43 & -0.39 & 0.11 & неврівноважений \\
\hline 36 & Balanced & -0.49 & 0.40 & 0.46 & -0.53 & 3.19 & 0.29 & -0.34 & -0.70 & 0.06 & виважений \\
\hline
\end{tabular}

Note. $\mathrm{Nr}$ - the ordinal number of the item in the list of adjectives, ICC - intraclass correlation coefficient; $M$ (mean), SD (standard deviation), As (asymmetry), $K$ (kurtosis) - descriptive statistics of items for 25 politicians (aggregated data from 583 raters).

The eigenvalues of the first ten unrotated principal components were as follows: $69.28,21.81,8.98,6.40,3.13,1.83,1.54,1.42,1.12$, and 1.00 .

\section{Appendix C. Supplementary information relating to the verification of the psychometric properties of the scales to measure perceived personality traits of politicians (see study III $\rightarrow$ method $\rightarrow$ questionnaire and procedure)}

See Fig. C1.

See Tables C1 and C2.

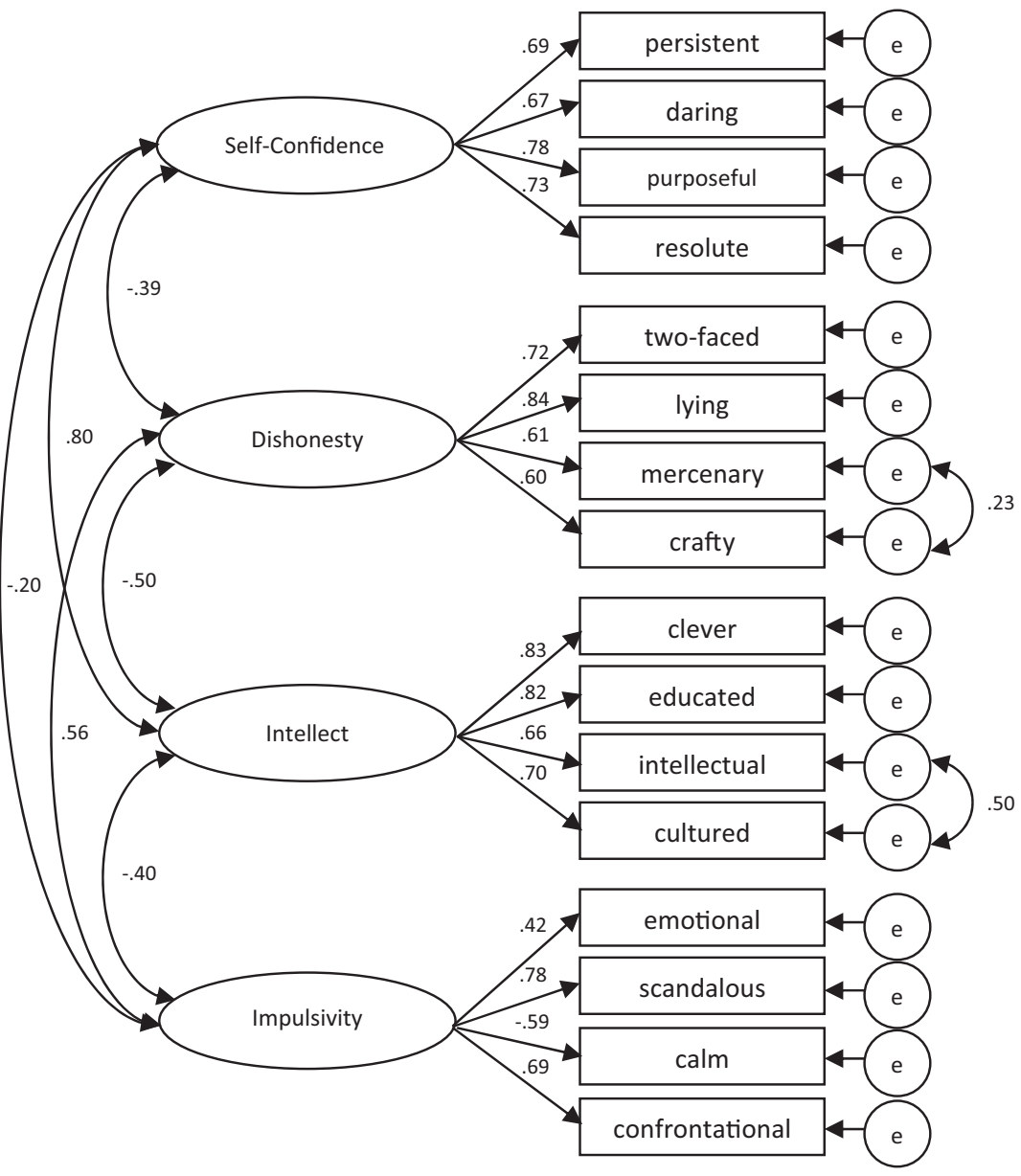

Fig. C1. Confirmatory factor analysis of short version of questionnaire. 
Table C1

The factor structure of the perception of politicians at the individual and aggregated levels.

\begin{tabular}{|c|c|c|c|c|c|c|c|c|c|}
\hline \multirow[t]{3}{*}{ Order in the list of adjectives } & \multirow[t]{3}{*}{ Adjectives } & \multicolumn{8}{|c|}{ Principal components } \\
\hline & & \multicolumn{4}{|c|}{ Individual level } & \multicolumn{4}{|c|}{ Agreggated level } \\
\hline & & 1 & 2 & 3 & 4 & 1 & 2 & 3 & 4 \\
\hline 10 & Persistent & 0.77 & -0.08 & 0.20 & 0.02 & 0.31 & 0.89 & 0.06 & 0.17 \\
\hline 13 & Daring & 0.74 & -0.21 & 0.11 & -0.05 & 0.13 & 0.89 & 0.08 & 0.36 \\
\hline 1 & Resolute & 0.74 & -0.05 & 0.12 & 0.07 & 0.08 & 0.94 & 0.17 & 0.17 \\
\hline 27 & Purposeful & 0.71 & -0.04 & 0.26 & 0.20 & 0.43 & 0.84 & -0.01 & 0.23 \\
\hline 6 & Strong & 0.70 & -0.21 & 0.17 & 0.02 & 0.13 & 0.89 & -0.03 & 0.34 \\
\hline 23 & Willed & 0.64 & -0.19 & 0.23 & 0.00 & 0.27 & 0.90 & 0.05 & 0.25 \\
\hline 20 & Leader & 0.56 & -0.29 & 0.38 & -0.04 & 0.37 & 0.88 & -0.05 & 0.09 \\
\hline 15 & Mercenary & -0.05 & 0.75 & -0.10 & -0.06 & -0.16 & -0.28 & 0.20 & -0.89 \\
\hline 7 & Lying & -0.18 & 0.75 & -0.19 & -0.20 & -0.38 & -0.22 & 0.31 & -0.81 \\
\hline 11 & Corrupt & -0.21 & 0.75 & -0.09 & -0.20 & -0.30 & -0.49 & 0.30 & -0.68 \\
\hline 28 & Crafty & -0.01 & 0.71 & -0.04 & -0.23 & -0.26 & -0.22 & 0.45 & -0.76 \\
\hline 3 & Two-faced & -0.21 & 0.70 & -0.08 & -0.15 & -0.30 & -0.31 & 0.21 & -0.85 \\
\hline 18 & Honest & 0.27 & -0.62 & 0.33 & 0.11 & 0.42 & 0.44 & -0.25 & 0.71 \\
\hline 21 & Sincere & 0.22 & -0.57 & 0.38 & 0.18 & 0.46 & 0.37 & -0.27 & 0.69 \\
\hline 19 & Orator & 0.20 & -0.16 & 0.76 & -0.08 & 0.89 & 0.26 & 0.11 & 0.25 \\
\hline 25 & Eloquent & 0.16 & -0.12 & 0.74 & -0.01 & 0.92 & 0.25 & 0.07 & 0.17 \\
\hline 22 & Intellectual & 0.28 & -0.18 & 0.64 & 0.25 & 0.85 & 0.30 & -0.27 & 0.25 \\
\hline 16 & Cultured & 0.30 & -0.17 & 0.62 & 0.30 & 0.87 & 0.16 & -0.31 & 0.23 \\
\hline 12 & Educated & 0.52 & -0.11 & 0.59 & 0.16 & 0.93 & 0.15 & -0.12 & 0.21 \\
\hline 8 & Clever & 0.50 & -0.15 & 0.52 & 0.17 & 0.86 & 0.32 & -0.13 & 0.21 \\
\hline 4 & Knowledgeable & 0.49 & -0.15 & 0.52 & 0.23 & 0.92 & 0.20 & -0.17 & 0.24 \\
\hline 14 & Calm & 0.21 & -0.10 & 0.18 & 0.71 & 0.18 & -0.12 & -0.90 & 0.18 \\
\hline 9 & Scandalous & -0.02 & 0.32 & -0.05 & -0.70 & -0.07 & 0.11 & 0.91 & -0.24 \\
\hline 26 & Restrained & 0.30 & -0.01 & 0.25 & 0.66 & 0.22 & 0.18 & -0.85 & 0.28 \\
\hline 17 & Confrontational & 0.00 & 0.25 & -0.10 & -0.63 & -0.10 & -0.09 & 0.93 & -0.23 \\
\hline 24 & Aggressive & 0.06 & 0.27 & 0.01 & -0.63 & -0.11 & 0.21 & 0.80 & -0.34 \\
\hline 5 & Emotional & 0.16 & 0.03 & 0.10 & -0.62 & 0.24 & 0.27 & 0.85 & 0.17 \\
\hline \multirow[t]{4}{*}{2} & Balanced & 0.37 & -0.11 & 0.26 & 0.55 & 0.43 & 0.30 & -0.73 & 0.35 \\
\hline & Eigenvalue & 4.9 & 4.0 & 3.7 & 3.4 & 7.2 & 7.1 & 6.0 & 5.5 \\
\hline & $\alpha$ & 0.87 & 0.87 & 0.88 & 0.81 & & & & \\
\hline & $r$ & 0.49 & 0.50 & 0.52 & 0.38 & & & & \\
\hline
\end{tabular}

Note. $\alpha$-Cronbach's alpha, $r$ - mean correlation between scale items.

Numbers in bold indicate strong component loadings.

Table C2

Politicians' perceived personality traits and voter preference.

\begin{tabular}{|c|c|c|c|c|c|c|}
\hline \multirow[t]{3}{*}{ Explanatory variables } & \multicolumn{6}{|c|}{ Response variables } \\
\hline & \multicolumn{3}{|c|}{ Individual level } & \multicolumn{3}{|c|}{ Agreggated level } \\
\hline & Attitude & Parliament & President & Attitude & Parliament & President \\
\hline \multicolumn{7}{|l|}{ beta coeff. } \\
\hline Dishonesty & $-0.42^{* *}$ & $-0.38^{* * *}$ & $-0.38^{* *}$ & $-0.59^{* *}$ & $-0.66^{* *}$ & $-0.62^{* *}$ \\
\hline Intellect & $0.32^{* *}$ & $0.22^{* *}$ & $0.20^{* *}$ & $0.44^{* *}$ & $0.28^{*}$ & $0.33^{*}$ \\
\hline Self-Confidence & $0.37^{* *}$ & $0.32^{* *}$ & $0.27^{* *}$ & $0.46^{* *}$ & $0.41^{*}$ & $0.36^{*}$ \\
\hline Impulsivity & $-0.28^{* *}$ & $-0.21^{* * *}$ & $-0.20^{* * *}$ & $-0.39^{* *}$ & $-0.38^{*}$ & $-0.36^{*}$ \\
\hline$R^{2}$ & 0.50 & 0.33 & 0.30 & 0.90 & 0.82 & 0.75 \\
\hline$F$ & $148.44^{* *}$ & $75.37^{* *}$ & $64.21^{* *}$ & $35.62^{* *}$ & $17.99^{* *}$ & $12.32^{* *}$ \\
\hline$d f_{1}, d f_{2}$ & 4,625 & 4,625 & 4,625 & 4,16 & 4,16 & 4,16 \\
\hline
\end{tabular}

${ }^{*} p<0.05$.

${ }^{* *} p<0.001$.

\section{References}

Allport, G. W., \& Odbert, H. S. (1936). Trait-names: A psycho-lexical study Psychological Monographs, 47(1), 1-171.

Almagor, M., Tellegen, A., \& Waller, N. G. (1995). The Big Seven model: A crosscultural replication and further exploration of the basic dimensions of natura language trait descriptors. Journal of Personality and Social Psychology, 69(2), 300-307.

Angleitner, A., Ostendorf, F., \& John, O. P. (1990). Towards a taxonomy of personality descriptors in German: A psycho-lexical study. European Journal of Personality, 4 (2), 89-118.

Ashton, M. C., Lee, K., Perugini, M., Szarota, P., de Vries, R. E., Di Blas, L., ... Boies, K. (2004). A six-factor structure of personality-descriptive adjectives: Solutions from psycholexical studies in seven languages. Journal of Personality and Social Psychology, 86(2), 356-366.

Bartels, L. M. (2002). The impact of candidate traits in American presidential elections. In A. King (Ed.), Leaders' personalities and the outcomes of democratic elections (pp. 44-69). Oxford: Oxford University Press.
Blais, A., \& St-Vincent, S. L. (2011). Personality traits, political attitudes and the propensity to vote. European Journal of Political Research, 50(3), 395-417.

Błaszczyk, E., \& Gorbaniuk, O. (2009). Wymiary postrzegania osobowości polskich polityków: analiza indywidualnych struktur czynnikowych. In J. Miluska (Ed.), Polityka $i$ politycy. Diagnozy-oceny-doświadczenia (pp. 263-278). Poznań: Wydawnictwo Naukowe UAM.

Brown, S. D., Lambert, R. D., Kay, B. J., \& Curtis, J. E. (1988). In the eye of the beholder: Leader images in Canada. Canadian Journal of Political Science, 21(4), 729-755.

Caballero, R. J. (1992). A fallacy of composition. American Economic Review, 82, 1279-1292.

Capelos, T. (2010). Feeling the issue: How citizens' affective reactions and leadership perceptions shape policy evaluations. Journal of Political Marketing, 9(1/2), 9-33.

Caprara, G. V., Barbaranelli, C., \& Zimbardo, P. G. (1997). Politicians uniquely restricted personalities. Nature, 385, 493.

Caprara, G. V., Barbaranelli, C., \& Zimbardo, P. G. (2002). When parsimony subdues distinctiveness: Simplified public perceptions of politicians' personality. Political Psychology, 23(1), 77-95. 
Caprara, G. V., Schwartz, S. H., Vecchione, M., \& Barbaranelli, C. (2008). The personalization of politics: Lessons from the Italian case. European Psychologist, 13(3), 157-172.

Caprara, G. V., \& Zimbardo, P. G. (2004). Personalizing politics: A congruency model of political preference. American Psychologist, 59(7), 581-594.

Catellani, P., \& Alberici, A. I. (2012). Does the candidate matter? Comparing the voting choice of early and late deciders. Political Psychology, 33(5), 619-634.

Costa, P., \& Ferreira da Silva, F. (2015). The impact of voter evaluations of leaders' traits on voting behaviour: Evidence from seven European countries. West European Politics, 38(6), 1226-1250.

Cwalina, W., Falkowski, A., \& Kaid, L. L. (2000). Role of advertising in forming the image of politicians: Comparative analysis of Poland, France, and Germany. Media Psychology, 2(2), 119-146.

Cwalina, W., Falkowski, A., Newman, B., \& Vercic, D. (2004). Models of voter behavior in traditional and evolving democracies. Journal of Political Marketing, 3(2), 7-30.

De Raad, B., \& Barelds, D. P. H. (2008). A new taxonomy of Dutch personality traits based on a comprehensive and unrestricted list of descriptors. Journal of Personality and Social Psychology, 94(2), 347-364.

De Raad, B., Barelds, D. P. H., Levert, E., Ostendorf, F., Mlačić, B., Blas, L. D., ... Hřebíčková, M. (2010). Only three factors of personality description are fully replicable across languages: A comparison of 14 trait taxonomies. Journal of Personality and Social Psychology, 98(1), 160-173.

de Raad, B., Hendriks, A. J., \& Hofstee, W. K. (1992). Towards a refined structure of personality traits. European Journal of Personality, 6(4), 301-319.

Everett, J. E. (1983). Factor comparability as a means of determining the number of factors and their rotation. Multivariate Behavioral Research, 18(2), 197-222.

Eysenck, H. J. (1991). Dimensions of personality: 16, 5 or 3? Criteria for a taxonomic paradigm. Personality and Individual Differences, 12(8), 773-790.

Fridkin, K. L., \& Kenney, P. J. (2011). The role of candidate traits in campaigns. Journal of Politics, 73(1), 61-73.

Funk, C. L. (1999). Bringing the candidate into models of candidate evaluation. Journal of Politics, 61(3), 700-721.

Garzia, D. (2011). The personalization of politics in Western democracies: Causes and consequences on leader-follower relationships. The Leadership Quarterly, 22 (4), 697-709.

Goldberg, L. R. (1981). Language and individual differences: The search for universals in personality lexicons. In L. Wheeler (Ed.). Review of Personality and Social Psychology (Vol. 2, pp. 141-165). Beverly Hills, CA: Sage.

Goldberg, L. R. (1990). An alternative "description of personality": The Big-Five factor structure. Journal of Personality and Social Psychology, 59(6), 1216-1229.

Gorbaniuk, O. (2009). Wymiary dyferencjacji profili osobowości polskich polityków: Analiza danych zagregowanych. Psychologia Społeczna, 1-2(10-11), 88-105.

Gorbaniuk, O., Kusak, K., Kogut, A., \& Kustos, M. (2015). Dimensions of political party “personality” perception. Journal of Political Marketing, 14(1), 35-63.

Gorbaniuk, O., Markiewicz, K., Bąkowicz, M., \& Ratajewska, A. (2010). Taksonomia leksykalna skojarzeń osobowych z polskimi politykami. Current Problems of Psychiatry, 11(1), 53-59.

Gorsuch, R. L. (1983). Factor analysis. Hillsdale, NJ: Erlbaum.

Guadagnoli, E., \& Velicer, W. F. (1988). Relation to sample size to the stability of component patterns. Psychological Bulletin, 103(2), 265-275.

Jakobwitz, S., \& Egan, V. (2006). The dark triad and normal personality traits. Personality and Individual Differences, 40(2), 331-339.

King, A. (2002). Do leaders' personalities really matter? In A. King (Ed.), Leaders' personalities and the outcomes of democratic elections (pp. 1-43). Oxford: Oxford University Press.
Koppensteiner, M., \& Grammer, K. (2010). Motion patterns in political speech and their influence on personality ratings. Journal of Research in Personality, 44(3), 374-379.

Koppensteiner, M., \& Stephan, P. (2014). Voting for a personality: Do first impressions and self-evaluations affect voting decisions? Journal of Research in Personality, 51, 62-68.

Koppensteiner, M., Stephan, P., \& Jäschke, J. P. M. (2015). More than words: Judgments of politicians and the role of different communication channels. Journal of Research in Personality, 58, 21-30.

Lorenzo-Seva, U., \& ten Berge, J. M. F. (2006). Tucker's congruence coefficient as a meaningful index of factor similarity. Methodology: European Journal of Research Methods for the Behavioral and Social Sciences, 2(2), 57-64.

Miller, A. H., \& Miller, W. E. (1976). Ideology in the 1972 election: Myth or reality. A rejoinder. The American Political Science Review, 70(3), 832-849.

Miller, A. H., Wattenberg, M. P., \& Malanchuk, O. (1986). Schematic assessments of presidential candidates. American Political Science Review, 80(2), 521-540.

O'Cass, A. (2002). A micromodel of voter choice: Understanding the dynamics of Australian voter characteristics in a federal election. Psychology \& Marketing, 19 (12), 1025-1046.

O'Cass, A., \& Pecotich, A. (2005). The dynamics of voter behavior and influence processes in electoral markets: A consumer behavior perspective. Journal of Business Research, 58(4), 406-413.

Ostroff, C. (1993). Comparing correlations based on individual-level and aggregated data. Journal of Applied Psychology, 78(4), 569-582.

Pancer, S. M., Brown, S. D., \& Barr, C. W. (1999). Forming impressions of political leaders: A cross-national comparison. Political Psychology, 20(2), 345-368.

Pancer, S. M., Brown, S. D., Gregor, P., \& Claxton-Oldfield, S. P. (1992). Causal attributions and the perception of political figures. Canadian Journal of Behavioural Science, 24(3), 371-381.

Peabody, D., \& Goldberg, L. R. (1989). Some determinants of factor structures from personality-trait descriptors. Journal of Personality and Social Psychology, 57(3), $552-567$.

Peterson, D. (2005). Heterogeneity and certainty in candidate evaluations. Political Behavior, 27(1), 1-24.

Robinson, W. S. (1950). Ecological correlations and the behavior of individuals American Sociological Review, 15(3), 351-357.

Saucier, G. (1997). Effects of variable selection on the factor structure of person descriptors. Journal of Personality and Social Psychology, 73(6), 1296-1312.

Saucier, G., \& Goldberg, L. R. (1996). The language of personality: Lexical perspectives on the five-factor model. In J. S. Wiggins (Ed.), The five-factor model of personality: Theoretical perspectives (pp. 21-50). New York, London: The Guilford Press.

Saucier, G., \& Srivastava, S. (2015). What makes a good structural model of personality? Evaluating the big five and alternatives. In M. Mikulincer, P. R. Shaver, M. L. Cooper, \& R. J. Larsen (Eds.), APA handbook of personality and social psychology. Personality processes and individual differences, APA handbooks in psychology (Vol. 4, pp. 283-305). Washington, DC, US: American Psychological Association.

Schoen, H., \& Schumann, S. (2007). Personality traits, partisan attitudes, and voting behavior. Evidence from Germany. Political Psychology, 28(4), 471-498.

Wang, C.-H. (2016). Personality traits, political attitudes and vote choice: Evidence from the United States. Electoral Studies, 44, 26-34.

Wattenberg, M. P. (1991). The rise of candidate-centered politics: Presidential elections of the 1980's. Cambridge, MA: Harvard University Press.

Winther Nielsen, S., \& Vinæs Larsen, M. (2014). Party brands and voting. Electoral Studies, 33, 153-165.

Wojciszke, B., \& Klusek, B. (1996). Moral and competence-related traits in political perception. Polish Psychological Bulletin, 27(4), 319-324. 